\title{
The importance of the viable but non-culturable state in human bacterial pathogens
}

\author{
Laam Li ${ }^{1}$, Nilmini Mendis ${ }^{1}$, Hana Trigui ${ }^{1}$, James D. Oliver ${ }^{2}$ and Sebastien P. Faucher ${ }^{1 *}$ \\ Department of Natural Resource Sciences, Faculty of Agricultural and Environmental Sciences, McGill University, Ste-Anne-de-Bellevue, QC, Canada \\ ${ }^{2}$ Department of Biology, University of North Carolina at Charlotte, Charlotte, NC, USA
}

\author{
Edited by: \\ Mickael Desvaux, INRA, France \\ Reviewed by: \\ Efstathios D. Giaouris, University of \\ the Aegean, Greece \\ Akos T. Kovacs, Friedrich Schiller \\ University of Jena, Germany \\ Joana Azeredo, University of Minho, \\ Portugal \\ *Correspondence: \\ Sebastien P. Faucher, Department of \\ Natural Resource Sciences, Faculty \\ of Agricultural and Environmental \\ Sciences, McGill University, 21,111 \\ Lakeshore, Ste-Anne-de-Bellevue, \\ Montreal, OC H9X 3V9, Canada \\ e-mail: sebastien.faucher2@ \\ mcgill.ca
}

Many bacterial species have been found to exist in a viable but non-culturable (VBNC) state since its discovery in 1982. VBNC cells are characterized by a loss of culturability on routine agar, which impairs their detection by conventional plate count techniques. This leads to an underestimation of total viable cells in environmental or clinical samples, and thus poses a risk to public health. In this review, we present recent findings on the VBNC state of human bacterial pathogens. The characteristics of VBNC cells, including the similarities and differences to viable, culturable cells and dead cells, and different detection methods are discussed. Exposure to various stresses can induce the VBNC state, and VBNC cells may be resuscitated back to culturable cells under suitable stimuli. The conditions that trigger the induction of the VBNC state and resuscitation from it are summarized and the mechanisms underlying these two processes are discussed. Last but not least, the significance of $\mathrm{VBNC}$ cells and their potential influence on human health are also reviewed.

Keywords: VBNC, stress, resuscitation, virulence, human pathogens, biofilm, antibiotic

\section{INTRODUCTION}

\section{CHARACTERISTICS OF VBNC CELLS}

Cultivation is one of the most fundamental steps in microbiology, and the plate count technique is one of the standard cultivation methods for the enumeration of viable bacteria (Buck, 1979; Talaro et al., 2002). However, it was first discovered in 1982 that Escherichia coli and Vibrio cholerae cells could enter a distinct state called the viable but non-culturable (VBNC) state (Xu et al., 1982). Unlike normal cells that are culturable on suitable media and develop into colonies, VBNC cells are living cells that have lost the ability to grow on routine media, on which they normally grow (Oliver, 2000).

Despite their non-culturability on normally permissive media, VBNC cells are not regarded as dead cells because of various dissimilarities. Dead cells have a damaged membrane that is unable to retain chromosomic and plasmidic DNA, while VBNC cells have an intact membrane containing undamaged genetic information (Heidelberg et al., 1997; Cook and Bolster, 2007). The plasmids, if any, are also retained in VBNC cells (Oliver, 2010). While dead cells are metabolically inactive, VBNC cells are metabolically active and carry out respiration (Lleò et al., 2000; Besnard et al., 2002). High ATP level was found in Listeria monocytogenes even one year after entering the VBNC state (Lindbäck et al., 2010). Moreover, dead cells do not express genes, while VBNC cells continue transcription and therefore, mRNA production (Lleò et al., 2000). In contrast to dead cells that no longer utilize nutrients, VBNC cells were shown to have continued uptake and incorporation of amino acids into proteins (Lleò et al., 1998).

Although VBNC cells have many general characteristics as a kind of viable cells, they have a lot of physiological and molecular differences from the viable, culturable cells. These differences include cellular morphology, cell wall and membrane composition, metabolism, gene expression, physical and chemical resistances, adhesion properties and virulence potential. In terms of cellular morphology, a reduction in cell size and thus, an increase in the surface area to volume ratio is commonly found in VBNC cells (Rahman et al., 1994; Du et al., 2007), probably as a strategy to minimize energy requirements (Postgate, 1976; Biosca et al., 1996). Apart from cell dwarfing, cell rounding is also found in VBNC cells of many species (e.g., Adams et al., 2003; Cook and Bolster, 2007). Campylobacter spp. changes from the characteristic spiral shape in the exponential phase to a coccoid shape in the VBNC state (Thomas et al., 2002). Burkholderia pseudomallei and $V$. cholerae cells also changes from rods during exponential growth to cocci in the VBNC state (Inglis and Sagripanti, 2006; Senoh et al., 2010). These morphological changes are commonly found in VBNC cells, however, similar changes are also found in nonVBNC cells that live under stressful conditions, so a change in morphology alone cannot be used as the sole parameter to judge whether the cells are in VBNC state or not (Pinto et al., 2013).

VBNC cells also show marked differences in cell wall and membrane composition, including proteins, fatty acids and peptidoglycan. Rearrangement of the outer membrane subproteome observed in E. coli was highly dependent on the conditions used to induce the VBNC state. For example, differential expression of three outer membrane proteins (Omp), antigen 43 $\beta$-subunit, TolC, and OmpT, was found in cells exposed to nutrient-limited phosphate buffered saline (PBS), and the most drastic changes showing 106 proteins being modulated were found in those exposed to natural seawater and light (Muela et al., 2008). Significant increases in the percentage of unsaturated fatty acids and fatty acids with less than 16 carbons were found in V.vulnificus entering the VBNC state, and significant 
changes in the percentage of hexadecanoic, hexadecenoic, and octadecanoic acids were found in the VBNC cells (Day and Oliver, 2004). Moreover, an increase in peptidoglycan cross-linking was observed in VBNC cells of Enterococcus faecalis (Signoretto et al., 2000).

VBNC cells have a lower metabolic rate (Shleeva et al., 2004) and a different gene expression profile compared to culturable cells growing in exponential phase. The expression of omp $W$ was significantly induced in VBNC cells of E. coli (Asakura et al., 2008). In VBNC cells of V. cholerae, a study showed that 58 genes related to regulatory functions, cellular processes, energy metabolism as well as transport and binding were induced by more than 5-fold (Asakura et al., 2007a), while another study reported a reduction in $16 \mathrm{~S}$ rRNA and the mRNA level of $t u f$, rpoS, and relA, genes responsible for protein synthesis and stress responses (González-Escalona et al., 2006).

In general, VBNC cells have higher physical and chemical resistance than culturable cells, which might be due to their reduced metabolic rate and a cell wall strengthened by increased peptidoglycan cross-linking (Signoretto et al., 2000). In terms of physical stress, VBNC cells of $V$. vulnificus are more resistant to mechanical destruction by sonication (Weichart and Kjelleberg, 1996), and those of Mycobacterium smegmatis are more resistant to high temperature (Anuchin et al., 2009). In terms of chemical stress, greater tolerance against low salinity and $\mathrm{pH}$, ethanol, chlorine, and antibiotics was observed in VBNC cells of V. parahaemolyticus (Wong and Wang, 2004), V. vulnificus (Weichart and Kjelleberg, 1996), Campylobacter jejuni (Rowe et al., 1998) and E. faecalis (Lleò et al., 2007a), respectively. A recent study has shown that $V$. vulnificus in VBNC state has a higher resistance to a variety of challenges, including heat, low $\mathrm{pH}$, ethanol, antibiotic, heavy metal, oxidative and osmotic stress, than those growing in exponential phase (Nowakowska and Oliver, 2013).

At this point it is necessary to differentiate between VBNC cells and persister cells. Persistence refers to the situation where a subpopulation is resistant to an antibiotic, whereas the bulk of the population is sensitive to this antibiotic. The persister cells are viewed as phenotypic variants in the population. To date, persister cells have only been characterized as being in a non-growing state and are antibiotic tolerant (Helaine and Kugelberg, 2014). In fact, VBNC cells have also been shown to be similarly antibiotic tolerant, as well as exhibiting tolerance to heavy metals, high and low temperature, high and low $\mathrm{pH}$, oxidative and osmotic challenges, and ethanol (Nowakowska and Oliver, 2013). Thus, the distinction between "persisters" and "viable but non culturable" cells appears artificial, and while there has been much published in recent years on the former, the literature on the latter is voluminous, and to date there are no convincing studies indicating they are not the same, or at least variants, of the same phenomenon (Wood et al., 2013). The phenotypes and metabolic programs of persister cells have been discussed in a recent review, and will not be covered here (Amato et al., 2014).

VBNC cells can also show changes in adhesion and virulence properties. For example, VBNC cells of $C$. jejuni retain their ability of attachment to stainless steel (Duffy and Dykes, 2009), while $V$. cholerae has a lower rate of adhesion to human intestinal cells (Pruzzo et al., 2003) and E. faecalis is unable to attach to plastic surfaces and initiate biofilm formation (Lleò et al., 2007b). L. monocytogenes in a VBNC state cannot cause infection (Cappelier et al., 2005; Lindbäck et al., 2010). In V. vulnificus, the progressive reduction of virulence is time dependent (Oliver and Bockian, 1995). Nonetheless, some VBNC cells are still virulent and even cause fatal infections, which may be due to rapid resuscitation into culturable cells in suitable hosts (Oliver and Bockian, 1995; Baffone et al., 2003; Du et al., 2007). The alterations in virulence, adhesion as well as resistance of VBNC cells account for their significance to public health (discussed in section Significances).

\section{THE OCCURRENCE OF VBNC CELLS AND THEIR IMPORTANCE}

Many species of bacteria enter the VBNC state when they are exposed to stressful conditions such as starvation and low temperatures (e.g., Biosca et al., 1996; Du et al., 2007), suggesting that this is an adaptive strategy for long-term survival of bacteria under unfavorable environmental conditions (Ducret et al., 2014). This hypothesis is supported by some characteristics of VBNC cells, including higher resistance to exogenous stresses, the ability of long-term survival under stress and the ability of resuscitation. For example, VBNC cells of V. parahaemolyticus are more resistant to acidity, allowing them to survive in an adverse environment with low pH (Wong and Wang, 2004). VBNC cells of $V$. fluvialis are viable after six years of starvation, suggesting that bacteria in VBNC state can stay alive over long periods of time, even under continued stress (Amel et al., 2008). More importantly, many species have the ability to resuscitate from the VBNC state back to the culturable state when the stress is removed (e.g., Roszak et al., 1984; Bates and Oliver, 2004). The evidence presented above supports the hypothesis that the VBNC state is a quiescent form of life allowing the organism to wait for suitable conditions to revive (Lleò et al., 2007a). Another hypothesis suggests that the VBNC state is a transitory stage in the degeneration of bacterial population leading to cell death (Thomas et al., 2002; Nyström, 2003). Nonetheless, there is not much evidence supporting the later hypothesis, so the former is generally accepted.

The ability to enter the VBNC state may be advantageous for bacteria, but poses a risk to human health. If VBNC cells are present, the total number of viable bacteria in a sample will be underestimated by the CFU count method due to the inherent non-culturability of VBNC cells. Even worse, if all bacteria in the sample are in VBNC state, the sample may be regarded as germfree due to non-detection. For bacterial species causing human infections, the underestimation or non-detection of viable cells in quality control samples from the food industry and water distribution systems, or clinical samples may pose serious risks to the public. The risks emerge from the fact that pathogenic bacteria can be avirulent in the VBNC state but regain virulence after resuscitation into culturable cells under suitable conditions (Du et al., 2007). This property of VBNC cells may lead to latency and subsequently, to the recurrence of disease in patients who were thought to be cured (Pai et al., 2000; Rivers and Steck, 2001). Therefore, it is of the utmost importance to understand what species of human pathogens can enter the VBNC state and apply reliable detection methods to quantify the accurate population of viable cells, including both culturable and VBNC cells. 
Apart from this, the identification of conditions that can induce bacteria to enter VBNC state and the underlying mechanisms, as well as the understanding of resuscitation conditions and mechanisms are necessary to effectively prevent bacterial infections and cure infected patients. In this review, the detection, induction, resuscitation and significance of VBNC cells will be discussed.

\section{DETECTION OF VBNC CELLS}

The two key properties of VBNC cells are viability and nonculturability, so the presence and abundance of VBNC cells can be determined by comparing the number of viable cells to that of culturable cells in the sample. As a general rule, if the number of culturable cells drops to an undetectable level while the number of viable cells remains high, then the population in the sample has become VBNC cells. Therefore, the first major step for the detection of VBNC cells is the estimation of the remaining culturable cells in the sample by a conventional plate count technique. For this step, it is important to use a rich medium without any additional stress, because some cells that may have been injured during exposure to different VBNC-inducing stresses may be unable to grow on selective or differential media with antibiotics or other stresses. These injured cells have a higher sensitivity to growth medium components that are not normally inhibitory, but they are not regarded as VBNC cells as they are culturable on non-selective media (Pinto et al., 2013). Thus, ensuring the most favorable growth condition allows injured cells to be eliminated from the VBNC population. For instance, after exposure to cold temperature, a population of $V$. vulnificus that normally grows on heart infusion (HI) agar supplemented with $20 \mu \mathrm{l}$ of $3 \%$ hydrogen peroxide $\left(\mathrm{H}_{2} \mathrm{O}_{2}\right)$ was only able to grow on $\mathrm{HI}$ agar with one-tenth concentration of $\mathrm{H}_{2} \mathrm{O}_{2}$ or less (Bogosian et al., 2000). Similarly, under temperature stress and starvation, C. jejuni became non-culturable on Karmali agar, which is a selective medium that suppresses the growth of unwanted bacterial species, but it remained culturable on non-selective Columbia blood agar (Cools et al., 2003).

The second major step for the detection of VBNC cells is the estimation of viable cells. One common method involves the use of a differential staining procedure and direct microscopic enumeration. The LIVE/DEAD ${ }^{\circledR}$ BacLight $^{\mathrm{TM}}$ assay consists of two fluorescent dyes with different cell permeability characteristics that can be used to differentiate cells with different membrane integrities (Cunningham et al., 2009). The green fluorescent dye, SYTO ${ }^{\circledR 9}$, penetrates both intact and damaged membrane and thus, labels all cells. The red fluorescent stain, propidium iodide, can only penetrate damaged membranes and label the injured cells and dead cells (Hurst, 1977). As a result, injured cells and dead cells would appear red under an epifluorescence microscope with suitable filter, while the culturable cells and VBNC cells with an intact membrane would appear green. The concentration of each dye and the appropriate parameters must be empirically validated for each bacterial species using appropriate controls to effectively differentiate between live and dead cells. Flow cytometry can be used with LIVE/DEAD ${ }^{\circledR}$ stains to easily obtain quantitative results (Allegra et al., 2008).

A second method is the detection of gene expression by reverse transcription polymerase chain reaction (RT-PCR). Due to the short half-life of mRNA, a positive signal indicates the presence of mRNA and thus, presence of viable cells that carry out transcription (Adams et al., 2003). As reviewed by Trevors (2011), this method is commonly used in many bacterial species to determine the viability of cells. For example, mRNAs from four housekeeping genes and four virulence genes were detected in a sample of $V$. parahaemolyticus after a 15-day incubation in freshwater at $4^{\circ} \mathrm{C}$ when the culturability was completely lost, suggesting the presence of VBNC cells (Coutard et al., 2007). The gene expression profile also helps understanding the potential phenotypes of VBNC cells. For example, the cadF gene, which encodes an outer membrane protein responsible for fibronectin-binding, was found to be continuously expressed in VBNC cells of C. jejuni that maintained the ability of adhesion (Patrone et al., 2013). Some studies have recommended specific genes for the detection of viable cells, such as $r f b E$ for E. coli (Yaron and Matthews, 2002) and pbp5 for E. faecalis (Lleò et al., 2000).

Other approaches can also be used to detect viable cells. The DNase I protection assay, another molecular method, can distinguish viable cells from dead cells, as only the viable cells have intact membranes to protect genomic DNA from digestion by exogenous nucleases. Using this method, Pawlowski et al. (2011) successfully demonstrated the presence of VBNC cells in a sample of Yersinia pestis with an undetectable level of culturable cells.

The direct count of viable bacterial cells (DVC) was first described by Kogure et al. (1979). It was found that viable cells cultured in a rich medium with antibiotics do not replicate but elongate, while dead cells remain unchanged. This method is highly dependent on the antibiotic sensitivity of the bacteria, so the use of nalidixic acid as the antibiotic, as was originally reported, may not be suitable for Gram-positive bacteria and some Gram-negative species (Byrd et al., 1991). Instead, aztreonam can be used for Cytophaga allerginae and Serratia marcescens (Heidelberg et al., 1997), and ciprofloxacin can be used for L. monocytogenes (Besnard et al., 2000). After incubation with antibiotics, acridine orange or 4',6-diamidino-2phenylindole (DAPI) can be used to stain the cells and illustrate changes in cellular morphology under microscope (Besnard et al., 2000; Du et al., 2007). Since the mechanisms underlying cell elongation in the presence of antibiotics are not fully understood, and the response of different bacteria to antibiotics may vary (Rice et al., 2000), this method is not commonly used.

Since viable cells, but not dead cells, carry out metabolic reactions and respiration, they can also be detected by the $p$-iodonitrotetrazolium violet (INT) assay based on the activity of electron transport system (Rahman et al., 1994). INT is a soluble tetrazolium salt that can compete with oxygen as the final electron acceptor and be reduced to insoluble formazan in metabolically active cells. Therefore, the formation and accumulation of formazan in cells, which appear as dark red precipitates under microscope, indicate the presence of an active electron transport chain, a characteristic of viable cells (Altman, 1970; Zimmermann et al., 1978). Similarly, another tetrazolium salt, 5-cyano-2,3-ditolyltetrazolium chloride (CTC) or the BacLight ${ }^{\mathrm{TM}}$ RedoxSensor ${ }^{\mathrm{TM}}$ Green can be used (Besnard et al., 2002; Lahtinen et al., 2008). Moreover, the luciferase assay can be used to estimate ATP generation in viable cells (Lindbäck et al., 2010). 
Because viable cells incorporate nutrients, they can also be detected by monitoring the uptake and incorporation of radiolabeled amino acids into protein. ${ }^{35} \mathrm{~S}$-labelled methionine, ${ }^{3} \mathrm{H}$ labelled leucine and ${ }^{35} \mathrm{~S}$-labelled cysteine/methionine have been used to detect viable cells in Shigella dysenteriae, E. faecalis and Y. pestis, respectively (Rahman et al., 1994; Lleò et al., 1998; Pawlowski et al., 2011).

\section{BACTERIA WITH A VBNC STATE}

In the past 10 years, several reviews have presented findings of bacteria that can exist in a VBNC state. For instance, Rowan (2004) has focused on foodborne and waterborne bacteria, Oliver (2010) has focused on bacteria that are pathogenic to plants, animals or humans and Pinto et al. (2013) have discussed both pathogenic and non-pathogenic bacteria. Currently, up to 85 species of bacteria have been found to exist in VBNC state in different environmental habitats or experimental conditions. Of these 85 species, 18 species are non-pathogenic and 67 species are pathogenic. The non-pathogenic species were generally found in fermented beverages. Sixteen of the pathogenic species cannot infect humans but can infect other organisms, including plants (Alexander et al., 1999; Grey and Steck, 2001; del Campo et al., 2009), fish (Magariños, Romalde, Barja and Toranzo, 1994; Oliver, 2010), and marine invertebrates such as shrimp (Sun et al., 2008), oysters (Williams et al., 2009), corals (Banin et al., 2000; Israely et al., 2001) and sea urchins (Masuda et al., 2004).

In this review, we specifically focus on bacteria that can cause human infections. Table 1 provides an overview of 51 human pathogens that have been reported to exist in a VBNC state, their inducing conditions, resuscitating conditions and the resuscitation window, if known. The list includes many true pathogens like E. coli and $Y$. pestis that cause disease in healthy individuals and may result in fatalities (Gourmelon et al., 1994; Pawlowski et al., 2011). It also includes some opportunistic human pathogens like Aeromonas hydrophila and Agrobacterium tumefaciens that mainly infect other organisms but also infect immunocompromised patients (Alexander et al., 1999; Rahman et al., 2001). Pathogenic bacteria that can enter a VBNC state have a broad phylogenetic distribution, suggesting that entering VBNC state may be a general strategy adopted by different lineages of bacteria to survive unfavorable conditions.

There is also broad environmental distribution of human pathogens that exist in a VBNC state. They are found in different kinds of water bodies, including seawater (Maalej et al., 2004; Dhiaf et al., 2008), estuarine water (Oliver et al., 1995), stream water (Lemke and Leff, 2006), lake water (Signoretto et al., 2004), ground water (Cook and Bolster, 2007), tap water (Pawlowski et al., 2011) and drinking water (Byrd et al., 1991). Moreover, VBNC cells of Salmonella typhimurium were found in soil (Reissbrodt et al., 2002) and those of E. coli were found in processed food (Makino et al., 2000). These findings support the idea that entering the VBNC state may be a common adaptive mechanism of bacteria inhabiting different, stressful environments, instead of a specific mechanism limited to bacteria living in a particular niche (Pinto et al., 2013).

\section{INDUCTION OF THE VBNC STATE CONDITIONS}

Although VBNC bacteria may remain viable for long periods of time, these cells lose their ability to grow on classical culture media on which they would normally develop into colonies (Oliver, 2005). It was shown that cells enter the VBNC state as a response to an extensive list of both chemically and environmentally unfavorable conditions (Oliver, 2010), including nutrient starvation (Cook and Bolster, 2007), extreme temperatures (Besnard et al., 2002), incubation outside the $\mathrm{pH}$ or salinity ranges that are permissive to cell growth (Cunningham et al., 2009), elevated or lowered osmotic concentrations (Asakura et al., 2008; Wong and Liu, 2008), fluctuating oxygen concentrations (Kana et al., 2008; Mascher et al., 2000), exposure to heavy metals (Ghezzi and Steck, 1999; del Campo et al., 2009), exposure to food preservatives (Quirós et al., 2009) and exposure to white light and UV irradiation (Gourmelon et al., 1994). In addition, treatments normally assumed to be bactericidal may instead result in the induction of the VBNC state in a subpopulation, including pasteurization of milk (Gunasekera et al., 2002) and chlorination of wastewater (Oliver, 2005).

To date, no large-scale studies have been performed to compare the effects of diverse conditions on the induction of VBNC state. Such a study is required to provide new information on the conditions that would lead to faster VBNC state inductions. Pinto et al. (2011) suggested that in E. coli, the origin of the strains and the incubation temperature are key factors for the speed at which VBNC cells appear in a bacterial population.

\section{REGULATORS OF THE VBNC STATE}

Despite the fact that the formation and the morphologi$\mathrm{cal} /$ physiological changes of the VBNC state have been well investigated (Barcina et al., 1997; Colwell and Grimes, 2000), little is known about the genetic control underlying this state. Since, there is a broad range of bacterial species that can enter the VBNC state, it is likely that there is also diversity in the regulatory mechanism. Understanding the molecular control of VBNC state would provide insight into its physiology, and may yield new information to develop novel detection methods or control methods for VBNC bacteria. To our knowledge, no systematic, large-scale screening of mutants for defects in VBNC state induction has ever been performed. Nevertheless, the regulators RpoS and OxyR seem to be important for the induction of VBNC state and are discussed below.

\section{RpoS}

A simple approach to identify VBNC genes consists of testing the influence of genes known to be involved in the response to other stressful environmental conditions, upon entry into VBNC state and during the survival of VBNC cells (McDougald et al., 2001). This led Boaretti et al. (2003) and Kusumoto et al. (2012) to analyse the involvement of the major stress regulator RpoS, a sigma factor essential for survival in the stationary phase and the general stress response (Lange and Hengge-Aronis, 1991; Hengge-Aronis, 1993). Indeed, RpoS depletion resulted in faster VBNC state induction in E. coli and Salmonella spp. (Kusumoto et al., 2012). The parental strain of $E$. coli became non-culturable in 33 days in 
Table 1 | The species of human pathogens with a proven VBNC state.

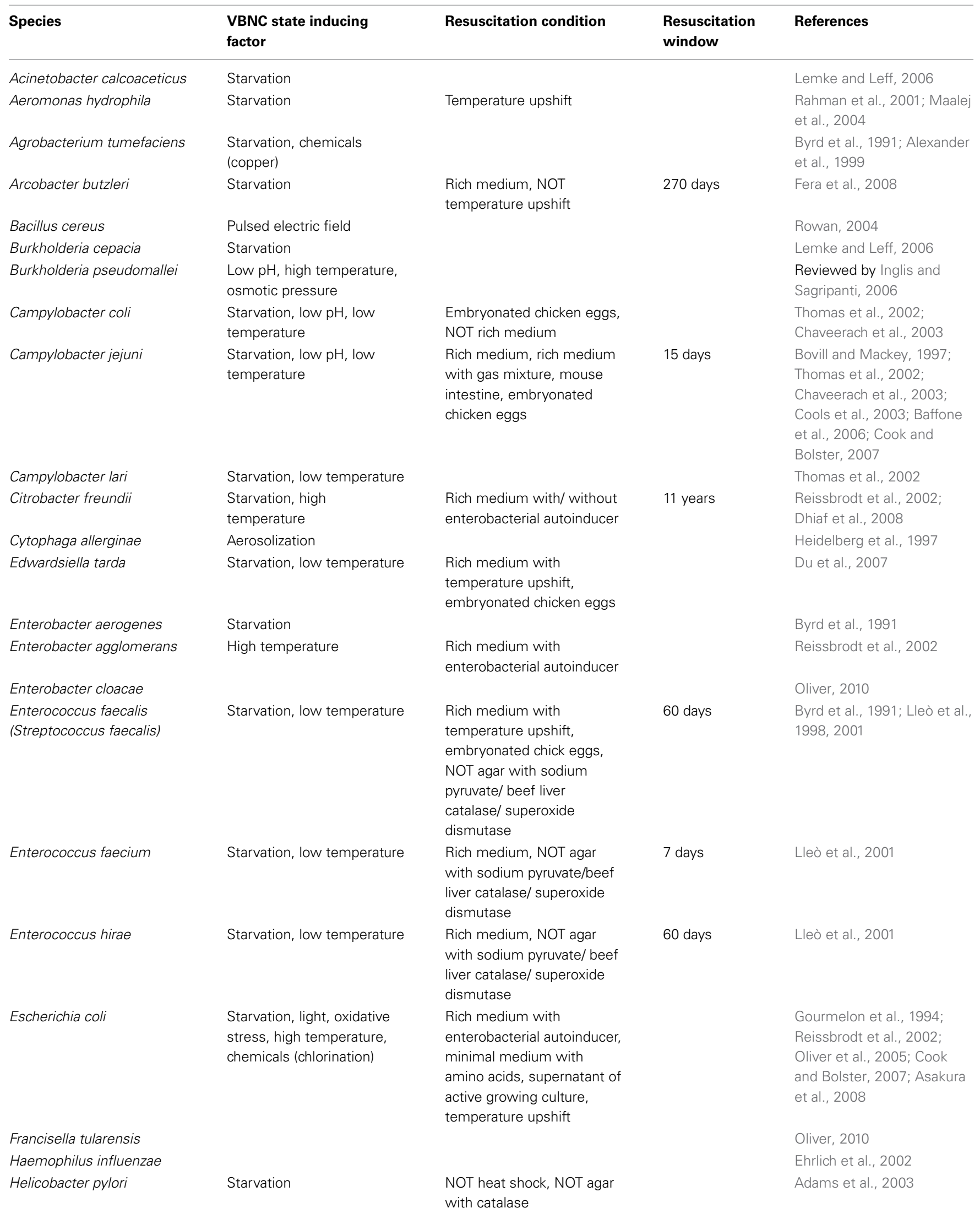


Table 1 | Continued

\begin{tabular}{|c|c|c|c|c|}
\hline Species & $\begin{array}{l}\text { VBNC state inducing } \\
\text { factor }\end{array}$ & Resuscitation condition & $\begin{array}{l}\text { Resuscitation } \\
\text { window }\end{array}$ & References \\
\hline Klebsiella aerogenes & & & & Oliver, 2010 \\
\hline Klebsiella pneumoniae & Starvation & & & Byrd et al., 1991 \\
\hline Legionella pneumophila & $\begin{array}{l}\text { Starvation, chemicals } \\
\text { (disinfectants } \mathrm{NaOCl} \text { and } \\
\mathrm{NH}_{2} \mathrm{Cl} \text { ), Hartmannella } \\
\text { vermiformis supernatant }\end{array}$ & Amoebae & & $\begin{array}{l}\text { Steinert et al., 1997; García } \\
\text { et al., 2007; Alleron et al., } \\
\text { 2008; Buse et al., } 2013\end{array}$ \\
\hline Listeria monocytogenes & $\begin{array}{l}\text { Starvation, low pH, low } \\
\text { temperature, low salinity, } \\
\text { chemicals (food } \\
\text { preservatives), light, pulsed } \\
\text { electric field }\end{array}$ & $\begin{array}{l}\text { NOT rich medium with/ } \\
\text { without sodium pyvurate }\end{array}$ & & $\begin{array}{l}\text { Besnard et al., 2002; } \\
\text { Rowan, 2004; Cunningham } \\
\text { et al., 2009; Lindbäck et al., } \\
2010\end{array}$ \\
\hline Mycobacterium smegmatis & $\begin{array}{l}\text { Starvation, oxygen } \\
\text { limitation, altered } \\
\text { temperature }\end{array}$ & $\begin{array}{l}\text { Rich medium, supernatant } \\
\text { of active growing culture, } \\
\text { Rpf }\end{array}$ & & $\begin{array}{l}\text { Kuznetsov et al., 2004; } \\
\text { Shleeva et al., } 2004\end{array}$ \\
\hline $\begin{array}{l}\text { Mycobacterium } \\
\text { tuberculosis }\end{array}$ & $\begin{array}{l}\text { Starvation, oxygen } \\
\text { limitation }\end{array}$ & Rich medium with catalase & 3.5 months & Downing et al., 2005 \\
\hline Pseudomonas aeruginosa & $\begin{array}{l}\text { Starvation, low } \\
\text { temperature, chemicals } \\
\text { (copper) }\end{array}$ & $\begin{array}{l}\text { Temperature upshift, rich } \\
\text { medium with copper } \\
\text { chelator }\end{array}$ & & $\begin{array}{l}\text { Leung et al., 1995; } \\
\text { Dwidjosiswojo et al., } 2011\end{array}$ \\
\hline Pseudomonas putida & Starvation & & & Lemke and Leff, 2006 \\
\hline Salmonella enteritidis & Starvation & Rich medium & $<21$ days & Roszak et al., 1984 \\
\hline Salmonella oranienburg & Starvation, salinity & $\begin{array}{l}\text { Rich medium with Rpfs, } \\
\text { supernatant from active } \\
\text { growing culture }\end{array}$ & & Panutdaporn et al., 2006 \\
\hline Serratia marcescens & Aerosolization & & & Heidelberg et al., 1997 \\
\hline Shigella dysenteriae & & & & Oliver, 1995 \\
\hline Shigella flexneri & & & & Oliver, 1995 \\
\hline Shigella sonnei & & & & Oliver, 1995 \\
\hline Staphylococcus aureus & & & & Zandri et al., 2012 \\
\hline Staphylococcus epidermidis & & & & Zandri et al., 2012 \\
\hline Vibrio alginolyticus & & & & Du et al., 2007 \\
\hline Vibrio cholera & Starvation, low temperature & $\begin{array}{l}\text { Human intestine, eukaryotic } \\
\text { cell lines, rabbit intestine }\end{array}$ & 110 days & $\begin{array}{l}\text { Colwell et al., 1985, 1996; } \\
\text { Senoh et al., } 2010\end{array}$ \\
\hline Vibrio fluvialis & Starvation & Rich medium & 6 years & Amel et al., 2008 \\
\hline Vibrio mimicus & & & & Oliver, 1995 \\
\hline Vibrio parahaemolyticus & $\begin{array}{l}\text { Starvation, low } \\
\text { temperature, low salinity }\end{array}$ & Temperature upshift & 2 weeks & $\begin{array}{l}\text { Bates and Oliver, 2004; } \\
\text { Wong and Wang, 2004; } \\
\text { Wong et al., } 2004\end{array}$ \\
\hline Vibrio vulnificus (type $1 \&$ 2) & Starvation, low temperature & $\begin{array}{l}\text { Rich medium, temperature } \\
\text { upshift, mice, clams }\end{array}$ & 3 days & $\begin{array}{l}\text { Nilsson et al., 1991; Oliver } \\
\text { and Bockian, 1995; Oliver } \\
\text { et al., 1995; Biosca et al., } \\
\text { 1996; Wong and Liu, } 2008\end{array}$ \\
\hline Yersinia pestis & Starvation, low temperature & Rich medium & & Pawlowski et al., 2011 \\
\hline
\end{tabular}

The inducing factors, resuscitating factors, as well as the longest resuscitation window reported are shown. 
an artificial oligotrophic medium incubated at $4^{\circ} \mathrm{C}$, whereas the rpoS mutant lost its culturability in only 21 days (Boaretti et al., 2003). Moreover, lack of rpoS resulted in a decreased ability to stay in VBNC state for long periods of time, resulting in faster cell death (Boaretti et al., 2003). Smith and Oliver (2006) reported that $V$. vulnificus continues to express rpoS in the VBNC state, suggesting that the stress-related genes regulated by rpoS are also likely to be expressed in VBNC state and lead to cross-protective effects. For example, once the bacteria encounter a stress, they produce a variety of proteins that serve to enhance survival under other stresses (Rangel, 2011).

In E. coli, RpoS mediates the expression of $10 \%$ of the genome upon exposure to stressful conditions (Gentry et al., 1993). It has been shown that induction of the stress response governed by RpoS involves the production of the alarmone guanosine tetraphosphate or pentaphosphate, ppGpp and pppGpp respectively [termed together as (p)ppGpp], and results in an increase in the amount of RpoS (Gentry et al., 1993). (p)ppGpp is a general indicator of the nutritional status of the cell and it lies on top of the regulatory network (Cashel et al., 1996). In Betaand Gammaproteobacteria, intracellular levels of (p)ppGpp are modulated by the RelA and SpoT proteins. RelA is a monofunctional alarmone synthase, and SpoT is a bifunctional synthase/hydrolase (Potrykus and Cashel, 2008). Both RelA and SpoT enzymes can synthesize (p)ppGpp, whereas SpoT can also hydrolyze it (Chatterji et al., 1998). It has been shown that, like the rpoS mutant, lack of (p)ppGpp production resulted in faster VBNC state induction (Boaretti et al., 2003). Overproducers of (p)ppGpp displayed viability comparable to that of $\Delta r p o S$ complemented strains or the wild-type strain (Boaretti et al., 2003). These findings suggest that the level of ( $\mathrm{p}$ )ppGpp may play a crucial role in the accumulation of RpoS, ultimately leading to enhanced stress resistance in VBNC cells. In V. cholerae, the entry into VBNC state changes the expression of relA which, in turn, modulates the (p)ppGpp level (González-Escalona et al., 2006; Asakura et al., 2007a). This may lead to further modulation of several major systems, including stress-response, replication and virulence systems. It is noteworthy that ppGpp also play a role in the production of persister cells as well (Amato et al., 2014).

\section{OxyR}

Cuny et al. (2005) suggested that reactive oxygen species (ROS) play a role in the formation of VBNC cells. When $E$. coli was subjected to $\mathrm{H}_{2} \mathrm{O}_{2}$ treatment, they entered the VBNC state (Arana et al., 1992). In addition, VBNC E. coli shows decreased superoxide dismutase activity, resulting in increased oxidative damage (Desnues et al., 2003). This suggests that regulation of the oxidative stress response is involved in the induction of VBNC state.

OxyR is a LysR-type transcriptional regulator and was first identified in S. typhimurium (Christman et al., 1985). It has a characteristic N-terminal DNA-binding domain, and is known to regulate oxidative stress-related genes (Tao et al., 1991; Wei et al., 2012). In V. vulnificus, mutation of $\operatorname{oxyR}$ results in loss of culturability after exposure to cold temperature, which can be relieved by cultivation under anaerobic conditions or with an exogenous supply of catalase (Kong et al., 2004). This study attributed the cold-induced loss of catalase activity to the induction of VBNC state, explaining why Vibrio spp. are almost undetectable during the winter months but re-emerge during the summer months, when temperature and nutrient level in seawater increase. In addition, two recent studies have investigated the role of two antioxidative enzymes, the alkyl hydroperoxide reductase subunit C (AhpC) (Wang et al., 2013) and the glutathione S-transferase (GST) (Abe et al., 2007), in the induction and maintenance of the VBNC state in V. parahaemolyticus and V. vulnificus, respectively (discussed in section Effectors Related to the Oxidative Stress Response). Knowing that OxyR regulates the expression of $a h p C$ in several Gram-negative bacteria in response to elevated ROS levels (Charoenlap et al., 2005; Hishinuma et al., 2006), and more recently, the expression of gst (Abgst01) in Acinetobacter baumannii in the presence of organic peroxides (Longkumer et al., 2014), we suggest that OxyR may be involved in the regulatory pathway leading to the induction of VBNC state. Direct evidence, such as quantification of ROS and antioxidative activities during the induction of VBNC state in the wild type and the oxyR mutant, is needed to further define the role of ROS in this state.

\section{EFFECTORS OF THE VBNC STATE \\ Effectors related to the metabolic pathways to obtain energy}

One line of research involves detecting proteins present exclusively in cells in the VBNC state (Heim et al., 2002; de Angelis and Gobbetti, 2004). Heim et al. (2002) studied changes in the proteome of E. faecalis in VBNC state after a 20-day incubation in lake water at $4^{\circ} \mathrm{C}$. Significant differences in protein profiles were observed among the exponentially growing cells, starved cells and VBNC cells. The proteomic analysis showed a significant down regulation of important proteins during the VBNC state: putative proteins enolase (glycolysis), ATP synthase (oxidative phosphorylation) and a homolog of the Staphylococcus aureus elongation factor EF-Tu (involved in protein synthesis, cell growth regulation and stress response). The repression of these genes seems in agreement with the decrease in metabolic activity observed in VBNC cells. On the other hand, three proteins were overexpressed in VBNC cells: a putative catabolite regulator protein (CAA09491), a homolog of the Listeria innocua elongation factor EF-Ts, and a homolog of the Streptococcus pneumoniae fructose bisphosphate aldolase. In this study, the genetic pathways of $E$. faecalis underlying the VBNC response appear to be, in part, the same as those leading to the starvation response, as indicated by the presence of similar expression profiles for certain proteins like enoyl-ACP reductase (phospholipid biosynthesis). Nonetheless, significant differences were also observed in the protein profiles between starved cells and VBNC cells. A protein homologous to the mannose-specific phosphotransferase system (PTS) of Clostridium acetobutylicum was only up-regulated in starved cells, and an unidentified protein $(30 \mathrm{kDa}$ at $\mathrm{pI} 6)$ was only detected in VBNC cells. While the specific function of this unidentified protein is still unclear, a comparison of $2 \mathrm{D}$ gels obtained from different cell states suggests that it may be a modified form of enoyl-ACP reductase.

In E. coli $\mathrm{O} 157: \mathrm{H7}$, entry into the VBNC state was observed after $48 \mathrm{~h}$ of incubation in PBS containing $0.05 \% \mathrm{H}_{2} \mathrm{O}_{2}$. Under this condition, $11 \%$ of the population maintained its membrane integrity. Incubation for $72 \mathrm{~h}$ led to a significant reduction in 
the number of cells with an intact membrane (Asakura et al., 2007b). The elongation factor EF-Tu, which was under-expressed in E. faecalis (Heim et al., 2002), maintained its expression level in E. coli, suggesting the maintenance of protein synthesis in the latter (Asakura et al., 2007b). The differences in the expression level of elongation factors between E. coli and E. faecalis suggest that the species as well as stress conditions are key factors in determining the mechanism involved in the induction of VBNC state.

A second line of research involves comparing the global transcription pattern of VBNC cells with that of cells grown in a rich medium (Asakura et al., 2007a,b). The transcriptomic analysis of $V$. vulnificus VBNC cells following incubation in artificial seawater at $4^{\circ} \mathrm{C}$ for 70 days has highlighted the induction and repression of hundreds of genes compared to stationary phase cells (Asakura et al., 2007a). The genes whose expression is significantly affected in the VBNC state are classified into the following functional groups: protein synthesis, energy metabolism, cell envelope, cellular processes, regulatory function, amino acid synthesis, and transport proteins. The genes expressed in the VBNC state include those involved in metal ion (iron, magnesium, potassium and cobalamin) transportation, chemotaxis and motility, pilus assembly and chitin utilization. All together, these findings indicate that both the proteomic and transcriptomic profiles of VBNC cells are different from those of cells that are either starved or exponentially growing. This demonstrates that the VBNC state constitutes a physiologically distinct state within the life cycle of a bacterium, which is activated in response to environmental stresses.

\section{Effectors related to the oxidative stress response}

The involvement of antioxidative factors in the VBNC state has been investigated (Bogosian et al., 2000; Wai et al., 2000). The addition of catalase or other ROS scavengers, such as sodium pyruvate, to the culture medium improves the culturability of VBNC cultures of A. hydrophila (Wai et al., 2000), E. coli (Mizunoe et al., 1999), and V. vulnificus (Bogosian et al., 2000).

Recently, Wang et al. (2013) investigated the antioxidative activities of alkyl hydroperoxide reductase subunit $\mathrm{C}$ ( $a h p C 1$ and ahpC2) against $\mathrm{H}_{2} \mathrm{O}_{2}$ and organic peroxide in $V$. parahaemolyticus in the context of the VBNC state and found that ahpC2 alone played a significant role in the induction and maintenance of the VBNC state at $4^{\circ} \mathrm{C}$. While an earlier study found an enhanced quantity of AhpC2 protein in the VBNC cells (Lai et al., 2009), the latest study showed that the transcripts of both $a h p C 1$ and ahpC2 decreased to low levels by approximately three orders of magnitude during the induction of the VBNC state (Wang et al., 2013). The protective function of $\mathrm{AhpC} 2$ at $4^{\circ} \mathrm{C}$ was higher than that of AhpC1. Indeed, the time required to induce and maintain the VBNC state at $4^{\circ} \mathrm{C}$ in a modified Morita mineral salt solution with $0.5 \% \mathrm{NaCl}$ in an ahpC2 mutant and an ahpClahpC2 double mutant was significantly shorter than that for the parental strain and the ahpC1 mutant (Wang et al., 2013). Complementation with an $a h p C 2$ gene reversed the effects of the ahpC2 mutation by increasing the time required for induction and maintenance of the VBNC state (Wang et al., 2013).

GST is another protein related to the oxidative stress response and is also involved in the VBNC state. It is a cytosolic protein that detoxifies endogenous compounds, such as peroxidized lipids, by conjugation with reduced glutathione (Marrs, 1996). In 2007, Abe et al. showed that a mutation causing over-expression of GST was responsible for the suppression of the ability to enter the VBNC state in V. vulnificus (Abe et al., 2007). Since GST is linked to the antioxidative response, the authors hypothesized that the induction of VBNC state is directly connected to oxidative stress, and that removing this stress would abolish the entry into VBNC state. This hypothesis was supported by Oliver (2010), who showed an important role of the V. vulnificus catalase KatG in its VBNC state. In this bacterium, expression of $k a t G$ is repressed upon the entry into VBNC state, but is induced when cells exit the VBNC state and become culturable again.

\section{Effectors related to the outer membrane proteins}

In Gram-negative bacteria, the outer membrane is an important physical and functional barrier separating the inside of cells and their surrounding environment. It consists of phospholipids, lipopolysaccharides and outer membrane proteins (OMPs) (Koebnik et al., 2000). Some OMPs, called porins, allow the passive diffusion of small, charged and uncharged molecules into bacterial cells (Nikaido and Vaara, 1985). In E. coli, the major outer membrane proteins are OmpF and OmpC (Misra and Reeves, 1987). Changes in the amount of OMPs in response to environmental stimuli have a major consequence on the survival of $E$. coli in stressful conditions, including starvation, changes in osmolarity and the VBNC state (Nikaido and Vaara, 1985; Özkanca and Flint, 2002; Darcan et al., 2009). In E. coli, the highest number of cells entering the VBNC state was found in an ompCompF double mutant strain compared to the wild-type and single mutants (Darcan et al., 2009). This is consistent with the phenotype of the ompCompF double mutant in S. typhimurium that lost culturability and entered the VBNC state when subjected to oxidative stress (Ozkanca et al., 2002).

The EnvZ/OmpR system regulates expression of the OmpF and OmpC proteins (Russo and Silhavy, 1991). OmpR is a cytoplasmic DNA-binding protein (Aiba et al., 1989). EnvZ is an environmental sensor bound to the inner membrane and has both kinase and phosphatase activities (Forst et al., 1987; Igo and Silhavy, 1988). Darcan et al. (2009) showed that the loss of the EnvZ protein has no effect on survival, but prevents the organism from sensing the changes in environment and thus, interfering with the entry into VBNC state. Indeed, env $Z$ mutants were found not to enter the VBNC state and stayed culturable for a longer period of time. Nonetheless, it is not clear if this phenotype is specific to the VBNC induction condition which, in this case, was osmotic stress.

\section{RESUSCITATION OF VBNC CELLS DETERMINATION OF THE RESUSCITATION}

It is important to note that bacteria that enter the VBNC state may become culturable again, and thus this state may be reversible. The term "resuscitation" was first used by Roszak et al. (1984) to describe the recovery of non-culturable cells of $S$. enteritidis subsequent to the addition of $\mathrm{HI}$ broth. Two decades later, Baffone et al. (2006) defined resuscitation as the reversal of metabolic and physiological changes that characterize VBNC cells. Of the 
species of human pathogens that can enter the VBNC state, resuscitation has been reported in only 26 species (17 genera) (Table 1). Resuscitation of these species was triggered by a variety of stimuli, such as an increase in temperature, increase in nutrients concentration, and the presence of host cells (discussed in section Factors Stimulating Resuscitation).

The first roadblock that researchers encountered when performing resuscitation studies is the difficulty to differentiate between the resuscitation of VBNC cells and the normal growth of residual culturable cells in a sample. To date, there are no readily available methods to distinguish between culturable cells that arise from resuscitation and those from normal growth after exposure to the stimuli. Therefore, the ideal timing to study resuscitation is when there are no more culturable cells present in the sample. Although the complete absence of culturable cells cannot be guaranteed because of the detection limits, resuscitation experiments are usually conducted after the number of culturable cells drops to an undetectable level, while the number of VBNC cells remains high (Biosca et al., 1996; Cappelier et al., 1999; Chaveerach et al., 2003; Downing et al., 2005). Some studies have carried out extra steps to minimize the number of culturable cells in the sample. For instance, Whitesides and Oliver (1997) performed serial dilutions to further reduce the proportion of culturable cells, and Lleò et al. (1998) used minimal inhibitory concentrations of antibiotics to kill the remaining culturable cells, but not the more resistant VBNC cells before starting resuscitation. Nonetheless, the use of antibiotics is not recommended, as it was found that antibiotics can prohibit the resuscitation of E. faecalis from the VBNC state by influencing cell wall biosynthesis (Lleò et al., 2007a).

\section{FACTORS AFFECTING RESUSCITATION}

Resuscitation has only been proven in half of the human pathogens that exist in the VBNC state, but this does not mean the others cannot be resuscitated at all. It is likely that the resuscitation requirements for the latter were never met. For example, Chaveerach et al. (2003) were able to resuscitate C. jejuni by incubating the VBNC cells in embryonated chicken eggs but not in rich medium, showing that the condition or stimulus required for resuscitation could be very specific. In fact, many factors can influence the successfulness of resuscitation, such as the strain used, the age of VBNC cells, the conditions that induced the VBNC state and, of course, the conditions provided for resuscitation (Pinto et al., 2011). A comprehensive study done by Pinto et al. (2011) clearly demonstrated the effects of these four factors on the resuscitation of $E$. coli. Their study showed that different strains of $E$. coli in a VBNC state can be resuscitated in different media, indicating that the resuscitation process is highly dependent on the strains and resuscitating conditions. It was also found that resuscitation only occurs within a limited period of time after entry into the VBNC state, so it is dependent on the age of VBNC cells. Furthermore, this study demonstrated that cells that were induced into a VBNC state at $4^{\circ} \mathrm{C}$ could be resuscitated by adding rich media, but those induced at room temperature could not be resuscitated by any of the 41 media tested, indicating that resuscitation also depends on the inducing conditions. Apart from the direct effects on resuscitation, the strain of bacteria may also interact with other factors regulating resuscitation. For example, the strain of $V$. parahaemolyticus can affect the period of time that the VBNC cells remain resuscitable (Wong et al., 2004), and the strain of $S$. typhimurium can affect the conditions required for resuscitation (Reissbrodt et al., 2002).

Pinto et al. (2013) first introduced the term "resuscitation window," which is defined as the period of time in which VBNC cells maintain their ability to resuscitate under suitable stimuli. When exposed to the inducing condition, different cells in a sample enter a VBNC state at different times. It was hypothesized that VBNC cells of the same species have a fixed resuscitation window, so the older VBNC cells will lose their resuscitation ability earlier than the younger VBNC cells, resulting in a reduction of total resuscitable cells over time. This is supported by Senoh et al. (2010), who reported a gradual reduction in the number of resuscitable cells from 74 to 91 days after $V$. cholerae entered a VBNC state. A similar reduction in the number of resuscitable cells over time in a VBNC population was also observed in E. faecalis and E. hirae (Lleò et al., 2001).

In most published studies, the cells' ability of resuscitation is tested right after the whole population has become VBNC. Therefore, not much information is available on the length of resuscitation window of different bacteria. Some studies report the successful resuscitation of VBNC cells at a particular age but do not repeat the resuscitation experiment at later time points, so the reported resuscitation window may be underestimated (Oliver and Bockian, 1995; Downing et al., 2005; Amel et al., 2008). There are only a few studies that have tried to determine the exact resuscitation window by studying the resuscitation of VBNC cells at different ages. Fera et al. (2008) investigated the VBNC cells of Arcobacter butzleri at four different ages and deduced that cells younger than 270 days can be resuscitated by addition of rich medium. Mukamolova et al. (1998b) found that 3-month-old and 6-month-old VBNC cells of Micrococcus luteus can be resuscitated within two months and 10 days, respectively, suggesting that the resuscitation window of this species is around six months. According to the available information, there is great variation in the resuscitation windows between different species (Table 1), ranging from 4 days in S. enteritidis (Roszak et al., 1984) to 11 years in Citrobacter freundii (Dhiaf et al., 2008).

\section{FACTORS STIMULATING RESUSCITATION}

Rich medium was the first stimulus found to resuscitate VBNC cells in S. enteritidis (Roszak et al., 1984). Since then, additional studies have examined a variety of stimuli that can trigger resuscitation. It was found that resuscitation can be mediated by a physical stimulus like temperature upshift (Maalej et al., 2004), and different kinds of chemical stimuli including gas mixtures (Bovill and Mackey, 1997), amino acids (Pinto et al., 2011), rich media (Amel et al., 2008), supernatant from actively growing cultures (Mukamolova et al., 1998b) or compounds secreted by actively growing cells (Reissbrodt et al., 2002; Panutdaporn et al., 2006), as well as the presence of host cells (Chaveerach et al., 2003). As mentioned previously, these stimuli may not be applicable to resuscitate all species or even the same species in different trials because of other interacting factors. For instance, temperature upshift can resuscitate VBNC cells of Pseudomonas 
aeruginosa (Leung et al., 1995) but not A. butzleri and Helicobacter pylori (Adams et al., 2003; Fera et al., 2008). Rich medium resuscitated C. jejuni in the study of Cools et al. (2003) but not in other studies (Chaveerach et al., 2003; Cook and Bolster, 2007). Among the human pathogens, C. jejuni, E. coli, and V. vulnificus are the three species that have been resuscitated by the greatest variety of stimuli (Table 1).

Interestingly, several studies have reported the unsuccessful resuscitation of VBNC cells after adding sodium pyruvate, catalase or superoxide dismutase onto agar plates (Lleò et al., 2001; Adams et al., 2003; Gupte et al., 2003; Lindbäck et al., 2010). These antioxidants can neutralize or prevent the formation of ROS such as $\mathrm{H}_{2} \mathrm{O}_{2}$ in the medium. These findings further prove that VBNC cells, in contrast to injured cells, do not lose their culturability solely because of sensitivity to ROS (Lleò et al., 2001). Some studies seem to contradict this view, showing that non-culturable cells can be recovered when agar plates are supplemented with ROS scavengers. For example, S. typhimurium was recovered by ferrioxamine E and oxyrase (Reissbrodt et al., 2002), V. vulnificus was recovered by catalase and pyruvate (Oliver, 2010), and Legionella pneumophila was recovered by pyruvate and glutamate (Ducret et al., 2014). However, further analysis of these studies show that the antioxidants only recovered a subpopulation (P1) of the non-culturable cells. In S. typhimurium, another subpopulation (P2) of non-culturable cells, which could not be recovered by supplementing with antioxidants, was resuscitated by another well-known resuscitation stimulus, an autoinducer (discussed in section Mechanisms of Resuscitation). These results suggest that $\mathrm{P} 1$ is composed of injured cells and P2 is composed of VBNC cells, so the increase in the number of culturable cells on antioxidant-supplemented agar was probably due to the recovery of injured cells instead of the resuscitation of VBNC cells.

\section{MECHANISMS OF RESUSCITATION Host cells}

The mechanisms underlying the resuscitation of VBNC cells remain largely unknown, especially for those triggered by host cells due to complicated bacteria-host interactions that are likely to play a major role. Bacteria in the VBNC state have been found to be resuscitated by amoebae (García et al., 2007), eukaryotic cell lines (Senoh et al., 2010), clams (Birbari et al., 2000), embryonated chicken eggs (Cappelier et al., 1999), mice (Baffone et al., 2006), rabbits (Colwell et al., 1985) and human volunteers (Colwell et al., 1996). These cells or animals are typically the natural host of the resuscitated bacteria. For example, the two species of amoeba, Acanthamoeba castellanii and A. polyphaga, that were shown to resuscitate VBNC cells of L. pneumophila, are the natural hosts of this bacterium (Steinert et al., 1997; García et al., 2007). Within the list of potential hosts, embryonated chicken egg can resuscitate the most species of VBNC cells, including Campylobacter coli (Chaveerach et al., 2003), C. jejuni (Cappelier et al., 1999), Edwardsiella tarda (Du et al., 2007) and E. faecalis (Lleò et al., 1998). This may be because of the high nutrient content of the yolk sac and/or the warm temperature during incubation.

\section{Removal of stress and presence of specific compounds}

Apart from resuscitation triggered by host cells, two requirements were proposed as being crucial for the occurrence of resuscitation. The first is the removal of external stress. It is known that bacteria enter a VBNC state under stressful conditions such as starvation and cold temperature, the two most common inducers (Table 1). Therefore, the addition of rich medium and/or the upshift of incubating temperature may allow the resuscitation of VBNC cells through elimination of the existing stress. Optimal medium concentration and incubation temperature are required for successful resuscitation. For starvation-induced VBNC cells of $M$. luteus, the proportion of cells being resuscitated depends strongly on the concentration of yeast extract in the medium. The optimal concentration depends on the age of VBNC cells, and a high concentration of yeast extract may damage the membranes of resuscitated cells, and consequently, affect their culturability (Mukamolova et al., 1998b). Similar to medium concentration, a temperature that is too high may prohibit resuscitation, as VBNC cells of $V$. parahaemolyticus that were induced by low temperature could be resuscitated at $22^{\circ} \mathrm{C}$ but not at $37^{\circ} \mathrm{C}$ (Wong et al., 2004). In contrary, more resuscitation of VBNC E. coli was observed at $37^{\circ} \mathrm{C}$ than at $25^{\circ} \mathrm{C}$ (Pinto et al., 2011), suggesting that the optimal temperature is species-dependent. Another evidence supporting the importance of stress removal in resuscitation was presented by Dwidjosiswojo et al. (2011). In their study, the VBNC cells of $P$. aeruginosa that were induced by copper ions were fully resuscitated in a solution containing the copper chelator diethyldithiocarbamate within 14 days.

The second hypothesis explaining resuscitation triggers is the presence of specific compounds as a signal. The compounds that were found to resuscitate VBNC cells include amino acids, resuscitation-promoting factors (Rpfs) and autoinducers (Mukamolova et al., 1998a; Reissbrodt et al., 2002; Pinto et al., 2011). Pinto et al. (2011) proposed that the resuscitation of VBNC cells is somehow similar to the germination of dormant spores, which can be triggered by specific amino acids (Atluri et al., 2006). Therefore, they tested the ability of VBNC E. coli to resuscitate under a minimal medium supplemented with different amino acids, and found that a combination of leucine, glutamine, methionine and threonine would be sufficient to trigger resuscitation of strain Eco3 (Pinto et al., 2011). It was suggested that these amino acids may bind to receptors on the cell surface or be transported into the cells to initiate resuscitation (Pinto et al., 2013).

$\boldsymbol{R} \boldsymbol{p f s}$. Rpf was first described by Mukamolova et al. (1998a) as a protein produced by Micrococcus luteus that can stimulate bacterial growth by reducing the lag phase and resuscitating VBNC cells in picomolar concentrations. This extracellular protein has been purified from the supernatant of $M$. luteus cultures growing in lactate minimal medium. It was found to have cross-species activity as it can affect the growth of five different Micrococcus species. Shleeva et al. (2004) have demonstrated the importance of Rpf by various methods. They successfully resuscitated the VBNC cells of Mycobacterium smegmatis by adding recombinant Rpf protein produced by $M$. luteus, co-culturing with $M$. luteus that secretes Rpf, as well as inserting a plasmid containing the $M$. 
luteus rpf gene for endogenous synthesis of Rpf. This study further suggested that $M$. smegmatis can produce its own Rpf-like protein, as the supernatant from a growing culture was able to resuscitate its VBNC cells.

In contrast to these two species, Mycobacterium tuberculosis produces five Rpf-like proteins, which are encoded by $r p f A$ to $r p f E$. These genes were thought to be functionally redundant and dispensable for growth, as the proteins seemed to have similar characteristics and properties (Mukamolova et al., 2002) and the deletion of all five genes did not affect the growth in rich medium (Kana et al., 2008). However, these five $r p f$ genes were expressed differently during exponential growth, exposure to stress and early resuscitation, suggesting they play different roles in bacterial growth and survival (Gupta et al., 2010). Moreover, the deletion of three $r p f$ genes prohibited the growth in mice as well as the resuscitation, demonstrating their functions cannot be compensated by the other two rpf genes, which were still present in this mutant strain (Downing et al., 2005). Kana et al. (2008) also reported that different combinations of $r p f$ gene deletions result in distinct changes to colony formation on agar plates, sensitivity to the detergent sodium dodecylsulphate and virulence in mice. All these findings suggest that the five Rpf proteins produced by M. tuberculosis are only partially redundant.

Three models have been proposed to explain the mechanism underlying Rpf-mediated resuscitation (Pinto et al., 2013). The first model suggests that Rpfs are cell-signaling molecules that are secreted by actively growing cells which can bind to the cell surface receptors on VBNC cells to initiate resuscitation. This model was first proposed by Mukamolova et al. (1998a) as Rpf, similar to other cell-signaling molecules, can stimulate cell growth and is likely to be involved in the control of cell replication.

The second model suggests that, instead of binding to receptors, Rpfs degrade or remodel the cell wall peptidoglycan of VBNC cells, thereby triggering resuscitation. Although no studies have demonstrated the molecular mechanisms underlying resuscitation triggered by peptidoglycan alteration, this model is supported by the fact that all Rpfs contain a conserved domain that is highly homologous to lysozyme and transglycosylase, which are both known to degrade the peptidoglycan of bacterial cell walls (Cohen-Gonsaud et al., 2005). Moreover, RpfB and RpfE were found to interact with Rpf-interacting protein A (RipA), which is a peptidoglycan hydrolase (Hett et al., 2007; Kana et al., 2008). The ability of Rpfs to degrade peptidoglycan via hydrolysis was recently demonstrated (Mukamolova et al., 2006), and this ability seems to be responsible for the resuscitation of $M$. smegmatis (Telkov et al., 2006). This suggests that the alteration of cell wall peptidoglycan may be crucial for the resuscitation of VBNC cells. It is noteworthy that the modification of the peptidoglycan layer was previously found to be involved in the induction of the VBNC state (Signoretto et al., 2000).

The third model is also based on the cleavage of peptidoglycan by Rpfs. However, instead of direct remodeling of the cell wall of VBNC cells, it suggests that the Rpfs cleave the peptidoglycan layer of the Rpf-producing cells and release small peptidoglycan fragments that bind to cell surface receptors of VBNC cells, thereby triggering resuscitation. This model was proposed because previous studies showed that some Rpfs are bound to the cell wall of Rpf-producing cells instead of being released into the growth medium (Mukamolova et al., 1998a; Koltunov et al., 2010). It was subsequently found that peptidoglycan fragments, either generated from Rpf digestion or ultrasonication, can stimulate the resuscitation of Micrococcus spp. (Nikitushkin et al., 2013). PknB is a Ser/Thr membrane kinase with an extracytoplasmic domain that binds peptidoglycan fragments. This protein may be responsible for the resuscitation mechanism, as it was demonstrated that a synthetic muropeptide with high affinity to PknB had a moderate effect on resuscitation (Mir et al., 2011). This model may also provide clues about the mechanism underlying resuscitation in animal models, since lysozymes produced by the immune system damage the peptidoglycan layer and could lead to the release of peptidoglycan subunits.

Autoinducers. Unlike the Rpfs that were only described in Micrococcus and Mycobacterium spp., heat-stable autoinducers are produced by a range of Gram-negative bacteria and some Grampositive bacteria. They were first found in cultures of E. coli growing in serum-SAPI medium supplemented with the human catecholamine hormone, norepinephrine (Freestone et al., 1999). Two years later, they were also found in cultures growing in four other kinds of media without the addition of norepinephrine (Freestone et al., 2001). Apart from thermal stability, these autoinducers are dialyzable, acid- and alkali-stable as well as protease-resistant (Weichart and Kell, 2001). E. coli were found to produce at least two kinds of autoinducer, AI-2 and AI-3 (Sperandio et al., 2003), which enter the target cells via a TonBdependent receptor (Freestone et al., 2001). In V. vulnificus, the addition of a LuxR inhibitor has been shown to delay the resuscitation mediated by AI-2, suggesting that this autoinducer is sensed by the master quorum sensing regulator SmcR (a LuxR homolog) (Ayrapetyan et al., 2014). In the same study, the authors found that RpoS is also important for AI-2 mediated resuscitation, and proposed that increased level of AI-2 stimulates rpoS expression through the action of LuxR, leading to resuscitation.

Similar to Rpfs, autoinducers can stimulate bacterial growth by reducing the lag phase (Freestone et al., 1999). In addition, they can be extracted from the supernatants of bacterial cultures and initiate resuscitation of VBNC cells of other bacterial species, demonstrating cross-species activity. It was found that the autoinducers from $E$. coli can resuscitate its own VBNC cells (Pinto et al., 2011), while the enterobacterial autoinducers from Y. ruckeri can resuscitate four species including C. freundii, E. coli, Enterobacter agglomerans, and S. typhimurium (Reissbrodt et al., 2002).

\section{Uncertainties waiting to be resolved}

The production of Rpfs and autoinducers by bacteria and the importance of these factors in resuscitation have raised another question: Does the resuscitation of VBNC cells require external stimuli or simply rely on factors produced by themselves or other bacterial species? Epstein (2009) proposed that bacteria can awake randomly without relying on environmental stimuli. According to this hypothesis, VBNC cells may resuscitate randomly, dying if the conditions are still unfavorable, or surviving if the conditions are permissive for growth. If the cells survive, they may divide to start a new population and/or secrete a signal 
to resuscitate other VBNC cells. Interestingly, a recent study have found that the level of autoinducer AI-2 in $V$. vulnificus reaches a peak $5 \mathrm{~h}$ after temperature upshift (a resuscitation-stimulating environmental stimulus), but the resuscitation of VBNC cells only became detectable an additional $2 \mathrm{~h}$ later (Ayrapetyan et al., 2014). The authors agreed to Epstein's hypothesis and suggested that resuscitation of the major population occurs after sensing the signal produced by a small, undetectable population of cells that resuscitated stochastically. Another possibility is that the signal is produced by cells remaining in VBNC state in response to a permissive environment, but no supporting or refuting evidences of this theory have ever been shown. Even if the signals have been proven to be produced by resuscitated cells, further investigation is still required to validate Epstein's hypothesis, as the current findings cannot confirm whether an undetectable number of cells resuscitated randomly before, or particularly after, the environment become suitable. The only conclusion that can be drawn is that particular environmental condition (e.g., temperature upshift or nutrient availability) is the prerequisite for the production of Rpfs or autoinducers and the resuscitation of the major population of VBNC cells.

Since the discovery of VBNC cells in the 1980s, few studies have investigated the molecular mechanisms underlying the process of resuscitation. It is known that the expression of ompW can regulate resuscitation in E. coli (Asakura et al., 2008) and the expression of $\operatorname{luxS}$ can affect AI-2 production and by consequence, resuscitation in V. vulnificus (Ayrapetyan et al., 2014). However, much more work is needed in order to understand the detailed mechanisms by which this gene and other genes induce the resuscitation of VBNC cells.

\section{SIGNIFICANCES \\ VBNC: CHANGING THE FACE OF PATHOGEN DETECTION}

More than 80 bacterial phyla have been identified to date; however, only about half of these have members that can be cultured in the laboratory (Pace, 2009; Stewart, 2012). Evidently, the history of microbiology has had a vested interest in microorganisms that have a direct influence on human health and food production, so most of the culturable species are either probiotics, pathogens, or those related to food spoilage. Until the discovery of the VBNC state (Xu et al., 1982), the presence and viability of these microorganisms were equated with their culturability on defined media. It is now increasingly clear that the potential threat presented by a given bacterial pathogen is not completely represented by its culturability on artificial media. Alternatives to culturing bacterial agents of disease use nucleic acid and antigenbased tests. While these are faster than culture methods, they are not without limitations making it worthwhile to invest energy into ameliorating current culture techniques (Cronquist et al., 2012; Jones and Gerner-Smidt, 2012). As discussed above, various VBNC-inducing conditions have been identified to date and these conditions are most likely just the tip of the iceberg. Research on the VBNC state is still in its infancy and in all likelihood, there are many more stresses that can induce a non-culturable state that are yet to be identified.

Entry into a VBNC state is considered as a bacterial response to exogenous stress. While these stresses may originate from the natural environment, what raises even more concern are the stresses induced by antimicrobial therapies and disinfectants used by humans to cure infections, obtain safe food and water sources, and sanitize environments. These may trigger bacteria to enter a VBNC state, especially when used inaccurately or in sub-lethal amounts. Noncompliance to drug regimens have been identified as a cause for the emergence of multidrug resistant strains of bacteria and this may well be a trigger for the VBNC state in some pathogens like M. tuberculosis (Kardas, 2002; Anderson et al., 2013).

More importantly, many documented VBNC inducing conditions are those in which humans encounter pathogens. For example, monochloramine treatment, which is used to sterilize drinking water, renders L. pneumophila VBNC, as does prolonged incubation in tap water (Steinert et al., 1997; Ducret et al., 2014). M. tuberculosis becomes VBNC under hypoxic conditions, theorized to be a stress encountered by the bacterium inside the tubercules of $M$. tuberculosis carriers (Fattorini et al., 2013; Manina and McKinney, 2013). V. vulnificus, a food-borne pathogen, enters the VBNC state in refrigerating temperatures (Nowakowska and Oliver, 2013).

Diagnosis of disease and identification of etiological agents have been and still are highly dependent upon culture techniques. The inability to culture microorganisms is then a major impasse for proper diagnosis of diseases and subsequent treatments, thus posing serious problems to pathogen detection, not only in the environment but also in food and water sources. As such, potentially dangerous contaminations can elude detection. In fact, VBNC bacteria have been found in human urine samples that were previously considered sterile (Anderson et al., 2001). Moreover, uncovering the secrets of the VBNC state may also provide clues to improve culture methods for the environmental bacteria that remain uncultivable as only $1 \%$ of the environmental bacterial population is thought to be cultured to date (Bloomfield et al., 1998). Giving the lack of novel antibiotics, enhanced culture techniques may lead to the discovery of new antimicrobial compounds.

\section{VBNC AND BIOFILM}

Biofilms are surface-attached, sessile bacterial communities enclosed in an extracellular matrix (ECM) (O'Toole et al., 2000). It has been estimated that $95 \%$ of bacteria present in water systems are found in biofilms (Flemming et al., 2002). Since water is a major source of contamination in food and an integral part of food production, and its contamination is the root of several nosocomial infections, focus on VBNC cells inside biofilms is of particular interest. While Kell and Young (2000) argue that the basis for the difference between dormancy and the VBNC state has been attributed to differences in metabolic activity, the literature suggests that both terms are describing the same physiological state of the cell. In the case of dormancy, the halt of cell division (leading to non-culturability) is viewed as a product of the dormant state while the VBNC state is defined by the inability of a cell to grow on laboratory media. Until our understanding of VBNC is deepened, this differentiation seems to be based on semantics and not necessarily on the actual presence of two different states. 
Several reports show that the heterotrophic plate count of biofilms from water samples do not reflect the total cell counts and this difficulty has been attributed to a VBNC status achieved within the biofilm (Wingender and Flemming, 2004; Lee et al., 2007). To date, little focus has been placed on studying VBNC cells in biofilms, but the prevalence and the threats associated with biofilms in medical settings will likely result in more rigorous research into this area of biofilm study. For example, C. jejuni, a food-borne bacterium, forms VBNC cells in biofilms where biocide resistance is increased (Newell and Fearnley, 2003). S. epidermidis in biofilms was found to enter a VBNC state when grown in media with an excess of glucose (Cerca et al., 2011). Interestingly, these VBNC cells induced a lower production of the cytokines TNF- $\alpha$ and IL-6, and replicated in macrophages to a lesser extent than their culturable counterparts leading to lower macrophage death. While the authors conclude that VBNC cells lead to a lower activation of macrophages, the CFU counts were only taken up to $9 \mathrm{~h}$ post-infection, which may not have been sufficiently long enough for resuscitation inside the host cells. VBNC Staphylococcus aureus and S. epidermidis cells have also been isolated from biofilms inside catheters (Zandri et al., 2012). More specifically, Pasquaroli et al. (2013) found that S. aureus entered a VBNC state upon exposure to antibiotics. However, subsequent resuscitation in response to sodium pyruvate makes it unclear whether the VBNC cells reported were, in fact, injured cells. More recently, L. monocytogenes, another important food-borne pathogen, was also shown to produce VBNC cells in biofilms (Gião and Keevil, 2014).

The microenvironment inside the biofilm structure is subjected to oxygen, $\mathrm{pH}$ and nutritional stresses; there is a lower nutrient availability and higher waste concentration deeper inside the biofilm than in the periphery (Stewart and Franklin, 2008). It is well established that bacteria in biofilms are starved and this starvation response confers antibiotic resistance (Nguyen et al., 2011). Such bacteria are thought to be thousand times more resistant to antimicrobials than their planktonic counterparts (Costerton et al., 1999). In multispecies biofilms, the culturability of L. pneumophila is influenced by the presence of other species (Gião et al., 2011). It is clear that much more rigorous research needs to be conducted to study the formation and impact of VBNC cells in biofilms.

\section{MYCOBACTERIUM TUBERCULOSIS: AN EXAMPLE OF NON-CULTURABLE CELLS IN VIVO}

The entry into the VBNC state has been identified in response to simulated environmental stresses and there is evidence of resuscitation in response to co-culture with host cells or their supernatants (Senoh et al., 2012). M. tuberculosis is known to enter VBNC state and resuscitate during infection of the host (i.e., human lungs). It is also well established that once the selective pressures for latency is absent, mainly in the form of immunosuppression, these dormant bacteria can cause active tuberculosis (TB). The VBNC state of M. tuberculosis (Mtb) is also known as latency or dormancy, and contributes to over two million Mtb carriers around the world (Gengenbacher and Kaufmann, 2012).

Once it invades alveolar macrophages, M. tuberculosis can hijack host cell machinery to halt phagosome maturation (Crowle et al., 1991; Sturgill-Koszycki et al., 1994; Vergne et al., 2004), but Mycobacterium spp. have also been shown to endure the stresses of a mature phagolysosome (Via et al., 1998). Latent $\mathrm{TB}$ is the result of solid granulomas containing M. tuberculosis, which is considered as VBNC cells because of decreased culturability (Gengenbacher and Kaufmann, 2012; Reece and Kaufmann, 2012). When the bacterium is non-culturable inside the human lung and alveolar macrophages, it does not cause any diagnosable symptoms until reactivation. Both in vitro (Wayne model) and in vivo (Cornell model) models are used to generate VBNC cells of M. tuberculosis in order to study bacterial and host factors contributing to the VBNC status (Wayne and Hayes, 1996; Scanga et al., 1999).

In the past 20 years, a growing body of research has been investigating Rpfs in M. tuberculosis and related mycobacteria that are at the root of latent TB reactivation (see section Mechanisms of Resuscitation). Mtb-derived Rpfs have been shown to increase the culturability of VBNC bacteria in clinical sputum samples (Mukamolova et al., 2010). More recently, highly specific free fatty acids have been identified as playing a role in a regulatory cascade involving Rpf proteins and adenylate cyclase, leading to the resuscitation of M. tuberculosis cells (Shleeva et al., 2013). The use of resuscitation knowledge in treating latent TB infections may be the next step in eliminating or reducing the disease burden.

\section{ANTIBACTERIAL RESISTANCE OF VBNC CELLS}

Because VBNC bacteria have a low metabolic rate, it is reasonable that antibacterials that target activities or components of active cells would be less effective against them. VBNC cells inside biofilms have an additional protection by the ECM. Moreover, the hypothesis that the VBNC state is an adaptation to stressful environments means that, by definition, these cells are likely to be less sensitive to exogenous stress. In M. tuberculosis, VBNC cells are relatively insensitive to isoniazid, which is an antibacterial drug targeting cell wall synthesis (involved in replication of active cell), but it is still used as a long-term therapy to treat the latent phase of disease (Manina and McKinney, 2013). The effectiveness of isoniazid in the long-term supports the idea that VBNC cells have in fact, adopted a slow metabolism. Therefore, the VBNC state may favor the development of drug resistance when strict drug regimens are not followed by allowing the bacterium to adapt before resuscitation. Oliver (2010) reviewed the antibiotic resistance in the VBNC state of some bacteria including E. faecalis, E. coli, Haemophilus influenza, H. pylori and M. smegmatis, all of which demonstrated an increased resistance to antibiotics. In addition, VBNC cells of $E$. coli are more resistant to sonication and that of $C$. jejuni are more heat resistant than non-VBNC cells (Klančnik et al., 2009; Zhao et al., 2013). Recently, an exponential phase cell culture and a VBNC cell culture of an environmental genotype strain of $V$. vulnificus were exposed to different challenges. It was found that the VBNC cells are more tolerant to a list of exogenous stresses, including high temperature $\left(50^{\circ} \mathrm{C}\right.$ for $1 \mathrm{~h}$ ), ethanol (final concentration of $13 \%$ for $1 \mathrm{~h}$ ), high salinity (c. $290 \mathrm{ppt}$ for $2 \mathrm{~h}$ ), oxidative stress $\left(0.2 \mathrm{mM} \mathrm{H}_{2} \mathrm{O}_{2}\right.$ for $\left.1 \mathrm{~h}\right)$, acidity ( $\mathrm{pH} 3$ for $25 \mathrm{~min}$ ), antibiotics (ampicillin or chloremphenical for $4 \mathrm{~h}$ ) and zinc $\left(3.4 \mathrm{mM} \mathrm{ZnSO}_{4} 7 \mathrm{H}_{2} \mathrm{O}\right.$ for $1 \mathrm{~h}$ ) (Nowakowska and Oliver, 2013). Interestingly, the same study demonstrated a 
lower resistance in VBNC cells of the clinical strain than those of the environmental strain, and proposed that these differences are based on the expression of certain genes (e.g., relA and katG).

\section{VIRULENCE AND VBNC IN OTHER PATHOGENS}

The recurrence of $M$. tuberculosis infections clearly proves that VBNC cells in the latent phase of the disease are able to retain or, in the least, regain their virulence potential upon resuscitation. In fact, since the VBNC state is a slow metabolic state, it would seem more likely that the observed virulence is a result of reactivation of the normal function of the cell (Oliver, 2010). In support of virulence maintenance in the VBNC state, VBNC L. pneumophila has been demonstrated to retain the capacity to infect the amoeba used for resuscitation, demonstrating virulence toward its natural host (Steinert et al., 1997; Al-Bana et al., 2013). Interestingly, another L. pneumophila strain showed continued production of virulence-related proteins in VBNC cells but could not be resuscitated in the same amoeba (Alleron et al., 2013). VBNC cells of Vibrio spp. have the ability to cause disease after resuscitation in their respective hosts (Baffone et al., 2003; Sun et al., 2008) and a microarray analysis of four Vibrio spp. revealed that a number of virulence and toxin genes were expressed in the VBNC state (Vora et al., 2005). VBNC S. typhi was also able to infect and cause disease in mouse models after resuscitation (Zeng et al., 2013). Much like the vibrios, E. coli O157:H7 was shown to produce Shigalike toxins, but the toxin levels produced were dependent upon the age and the inducing condition of the VBNC cells (Liu et al., 2010).

These data on VBNC virulence suggests that, much like VBNC inducing stimuli and resuscitation factors, the expression and maintenance of virulence in different species of VBNC cells can vary greatly. $P$. aeruginosa is an important pathogen in terms of the disease burden and mortality associated with infection. It colonizes lung tissues of cystic fibrosis patients and is difficult to completely eradicate as it resides in biofilms in the lungs (Mulcahy et al., 2013). Given that VBNC cells can occur inside biofilms, relatively little progress has been made to study resuscitation factors of $P$. aeruginosa in this environment.

This capacity of resuscitation with no apparent loss of virulence potential evidently brings about concerns regarding the presence of VBNC bacteria not only in a medical context with respiratory pathogens like $M$. tuberculosis, L. pneumophila, and $P$. aeruginosa but also in relation to food safety (Dinu and Bach, 2011). In the case of $P$. aeruginosa, great strides toward reducing the bacterial load in CF patients could be made by inducing resuscitation of the VBNC bacteria inside the human host which would then be more susceptible to antibiotics. It is an avenue of research that is worth exploring.

\section{CONCLUSION}

After decades of study, it is clear that the VBNC state is both an important tool for the survival of bacteria and a dangerous aspect of bacterial pathogens for the host. The knowledge about the VBNC state comes from research on a variety of bacteria and highlights the complexity of this mechanism of adaptation. What seems clear is that induction and resuscitation of the VBNC state are highly variable across bacterial species and in some cases, strains. However, the basic genetic mechanisms may share a common theme and further research into this field will help tie up the loose ends that exist in this area. The ability to avoid conditions that lead to resuscitation, or the development of drugs that induce resuscitation during antibiotherapy could have a major impact on the consequence of the VBNC state in chronic infectious diseases. Development of new, inexpensive methods to easily detect cells in the VBNC state is needed to increase food safety. In conclusion, the potential applications of VBNC research are significant to prevent food- and water-borne infections, and find new treatments to cure chronic bacterial infections.

\section{ACKNOWLEDGMENT}

Work in Dr. Faucher's laboratory is supported by the NSERC Discovery Grant 418289-2012.

\section{REFERENCES}

Abe, A., Ohashi, E., Ren, H., Hayashi, T., and Endo, H. (2007). Isolation and characterization of a cold-induced nonculturable suppression mutant of Vibrio vulnificus. Microbiol. Res. 162, 130-138. doi: 10.1016/j.micres.2006. 01.007

Adams, B. L., Bates, T. C., and Oliver, J. D. (2003). Survival of Helicobacter pylori in a natural freshwater environment. Appl. Environ. Microbiol. 69, 7462-7466. doi: 10.1128/AEM.69.12.7462-7466.2003

Aiba, H., Nakasai, F., Mizushima, S., and Mizuno, T. (1989). Evidence for the physiological importance of the phosphotransfer between the two regulatory components, EnvZ and OmpR, in osmoregulation in Escherichia coli. J. Biol. Chem. 264, 14090-14094.

Al-Bana, B. H., Haddad, M. T., and Garduño, R. A. (2013). Stationary phase and mature infectious forms of Legionella pneumophila produce distinct viable but non-culturable cells. Environ. Microbiol. 2, 382-395. doi: 10.1111/14622920.12219

Alexander, E., Pham, D., and Steck, T. R. (1999). The viable-but-nonculturable condition is induced by copper in Agrobacterium tumefaciens and Rhizobium leguminosarum. Appl. Environ. Microbiol. 65, 3754-3756.

Allegra, S., Berger, F., Berthelot, P., Grattard, F., Pozzetto, B., and Riffard, S. (2008). Use of flow cytometry to monitor Legionella viability. Appl. Environ. Microbiol. 74, 7813-7816. doi: 10.1128/AEM.01364-08

Alleron, L., Khemiri, A., Koubar, M., Lacombe, C., Coquet, L., Cosette, P., et al. (2013). VBNC Legionella pneumophila cells are still able to produce virulence proteins. Water Res. 47, 6606-6617. doi: 10.1016/j.watres.2013.08.032

Alleron, L., Merlet, N., Lacombe, C., and Frère, J. (2008). Long-term survival of Legionella pneumophila in the viable but nonculturable state after monochloramine treatment. Curr. Microbiol. 57, 497-502. doi: 10.1007/s00284-0089275-9

Altman, F. P. (1970). On the oxygen-sensitivity of various tetrazolium salts. Histochemie 22, 256-261. doi: 10.1007/bf00306103

Amato, S. M., Fazen, C. H., Henry, T., Mok, W. W., Orman, M. A., Sandvik, E. L., et al. (2014). The role of metabolism in bacterial persistence. Front. Microbiol. 5:70. doi: 10.3389/fmicb.2014.00070

Amel, B. K.-N., Amine, B., and Amina, B. (2008). Survival of Vibrio fluvialis in seawater under starvation conditions. Microbiol. Res. 163, 323-328. doi: 10.1016/j.micres.2006.06.006

Anderson, L. F., Tamne, S., Watson, J. P., Cohen, T., Mitnick, C., Brown, T., et al. (2013). Treatment outcome of multi-drug resistant Tuberculosis in the United Kingdom: retrospective-prospective cohort study from 2004 to 2007. Euro. Surveill. 18:20601. doi: 10.2807/1560-7917.ES2013.18.40.20601

Anderson, M., Bollinger, D., Hagler, A., Hartwell, H., Rivers, B., Ward, K., et al. (2001). Viable but nonculturable bacteria are present in mouse and human urine specimens. J. Clin. Microbiol. 42, 753-758. doi: 10.1128/JCM.42.2.753758.2004

Anuchin, A. M., Mulyukin, A. L., Suzina, N. E., Duda, V. I., El-Registan, G. I., and Kaprelyants, A. S. (2009). Dormant forms of Mycobacterium smegmatis with distinct morphology. Microbiology 155, 1071-1079. doi: 10.1099/mic.0.02 3028-0 
Arana, I., Muela, A., Iriberri, J., Egea, L., and Barcina, I. (1992). Role of hydrogen peroxide in loss of culturability mediated by visible light in Escherichia coli in a freshwater ecosystem. Appl. Environ. Microbiol 58, 3903-3907.

Asakura, H., Ishiwa, A., Arakawa, E., Makino, S-I, Okada, Y., Yamamoto, S., et al. (2007a). Gene expression profile of Vibrio cholerae in the cold stressinduced viable but non-culturable state. Environ. Microbiol. 9, 869-879. doi: 10.1111/j.1462-2920.2006.01206.x

Asakura, H., Kawamoto, K., Haishima, Y., Igimi, S., Yamamoto, S., and Makino, S.I. (2008). Differential expression of the outer membrane protein W (OmpW) stress response in enterohemorrhagic Escherichia coli O157:H7 corresponds to the viable but non-culturable state. Res. Microbiol. 159, 709-717. doi: 10.1016/j.resmic.2008.08.005

Asakura, H., Panutdaporn, N., Kawamoto, K., Igimi, S., Yamamoto, S., and Makino, S.-I. (2007b). Proteomic characterization of enterohemorrhagic Escherichia coli O157:H7 in the oxidation-induced viable but non-culturable state. Microbiol. Immunol. 51, 875. doi: 10.1111/j.1348-0421.2007.tb03969.x

Atluri, S., Ragkousi, K., Cortezzo, D. E., and Setlow, P. (2006). Cooperativity between different nutrient receptors in germination of spores of Bacillus subtilis and reduction of this cooperativity by alterations in the GerB receptor. J. Bacteriol. 188, 28-36. doi: 10.1128/JB.188.1.28-36.2006

Ayrapetyan, M., Williams, T. C., and Oliver, J. D. (2014). Interspecific quorum sensing mediates the resuscitation of viable but nonculturable vibrios. Appl. Environ. Microbiol. 80, 2478-2483. doi: 10.1128/AEM.00080-14

Baffone, W., Casaroli, A., Citterio, B., Pierfelici, L., Campana, R., Vittoria, E., et al. (2006). Campylobacter jejuni loss of culturability in aqueous microcosms and ability to resuscitate in a mouse model. Int. J. Food Microbiol. 107, 83-91. doi: 10.1016/j.ijfoodmicro.2005.08.015

Baffone, W., Citterio, B., Vittoria, E., Casaroli, A., Campana, R., Falzano, L., et al. (2003). Retention of virulence in viable but non-culturable halophilic Vibrio spp. Int. J. Food. Microbiol. 89, 31-39. doi: 10.1016/S0168-1605(03)0 0102-8

Banin, E., Israely, T., Kushmaro, A., Loya, Y., Orr, E., and Rosenberg, E. (2000). Penetration of the coral-bleaching bacterium Vibrio shiloi into Oculina patagonica. Appl. Environ. Microbiol. 66, 3031-3036. doi: 10.1128/AEM.66.7.30313036.2000

Barcina, I., Lebaron, P., and Vives-Rego, J. (1997). Survival of allochthonous bacteria in aquatic systems: a biological approach. FEMS Microbiol. Ecol. 23, 1-9. doi: 10.1111/j.1574-6941.1997.tb00385.x

Bates, T. C., and Oliver, J. D. (2004). The viable but nonculturable state of kanagawa positive and negative strains of Vibrio parahaemolyticus. J. Microbiol. 42, 74-79.

Besnard, V., Federighi, M., and Cappelier, J. M. (2000). Evidence of viable but nonculturable state in Listeria monocytogenes by direct viable count and CTC-DAPI double staining. Food Microbiol. 17, 697-704. doi: 10.1006/fmic.2000.0366

Besnard, V., Federighi, M., Declerq, E., Jugiau, F., and Cappelier, J. M. (2002). Environmental and physico-chemical factors induce VBNC state in Listeria monocytogenes. Vet. Res. 33, 359-370. doi: 10.1051/vetres:2002022

Biosca, E. G., Amaro, C., Marco-Noales, E., and Oliver, J. D. (1996). Effect of low temperature on starvation-survival of the eel pathogen Vibrio vulnificus biotype 2. Appl. Environ. Microbiol. 62, 450-455.

Birbari, W., Wright, A., and Rodrick, G. (2000). Viable but non-culturable response for phase variants of Vibrio vulnificus in clams. J. Shellfish Res. 19, 660.

Bloomfield, S. F., Stewart, G. S., Dodd, C. E., Booth, I. R., and Power, E. G. (1998) The viable but non-culturable phenomenon explained? Microbiology 144, 1-3. doi: 10.1099/00221287-144-1-1

Boaretti, M., Lleò, M. M., Bonato, B., Signoretto, C., and Canepari, P. (2003). Involvement of rpoS in the survival of Escherichia coli in the viable but non-culturable state. Environ. Microbiol. 5, 986-996. doi: 10.1046/j.14622920.2003.00497.x

Bogosian, G., Aardema, N. D., Bourneuf, E. V., Morris, P. J., and O’Neil, J. P. (2000). Recovery of hydrogen peroxide-sensitive culturable cells of Vibrio vulnificus gives the appearance of resuscitation from a viable but nonculturable state. J. Bacteriol. 182, 5070-5075. doi: 10.1128/JB.182.18.5070-5075.2000

Bovill, R. A., and Mackey, B. M. (1997). Resuscitation of 'non-culturable' cells from aged cultures of Campylobacter jejuni. Microbiology 143, 1575-1581.

Buck, J. (1979). "The plate count in aquatic microbiology," in Native Aquatic Bacteria: Enumeration, Activity and Ecology, eds J. W. Costerton, and R. R. Colwell (Philadelphia, PA: American Society for Testing and Materials), 19-28. doi: 10.1520/STP36000S
Buse, H. Y., Donohue, M. J., and Ashbolt, N. J. (2013). Hartmannella vermiformis inhibition of Legionella pneumophila cultivability. Microbiol. Ecol. 66, 715-726. doi: 10.1007/s00248-013-0250-Z

Byrd, J. J., Xu, H. S., and Colwell, R. R. (1991). Viable but nonculturable bacteria in drinking water. Appl. Environ. Microbiol. 57, 875-878.

Cappelier, J. M., Besnard, V., Roche, S., Garrec, N., Zundel, E., Velge, P., et al. (2005). Avirulence of viable but non-culturable Listeria monocytogenes cells demonstrated by in vitro and in vivo models. Vet. Res. 36, 589-599. doi: 10.1051/vetres:2005018

Cappelier, J. M., Minet, J., Magras, C., Colwell, R. R., and Federighi, M. (1999). Recovery in embryonated eggs of viable but nonculturable Campylobacter jejuni cells and maintenance of ability to adhere to HeLa cells after resuscitation. Appl. Environ. Microbiol. 65, 5154-5157.

Caro, A., Got, P., Lesne, J., Binard, S., and Baleux, B. (1999). Viability and virulence of experimentally stressed nonculturable Salmonella typhimurium. Appl. Environ. Microbiol. 65, 3229-3232.

Cashel, M., Gentry, D. R., Hernandez, V. J., and Vinella, D. (1996) “The stringent response," in Escherichia coli and Salmonella typhimurium: Cellular and Molecular Biology, eds F. C. Neidhardt, R. Curtiss III, J. L. Ingraham, E. C. C. Lin, K. B. Low, B. Magasanik, et al. (Washington, DC: ASM Press), 1458-1496.

Cerca, F., Andrade, F., França, Â., Andrade, E. B., Ribeiro, A., Almeida, A. A., et al. (2011). Staphylococcus epidermidis biofilms with higher proportions of dormant bacteria induce a lower activation of murine macrophages. J. Med. Microbiol. 60, 1717-1724. doi: 10.1099/jmm.0.031922-0

Charoenlap, N., Eiamphungporn, W., Chauvatcharin, N., Utamapongchai, S., Vattanaviboon, P., and Mongkolsuk, S. (2005). OxyR mediated compensatory expression between ahpC and katA and the significance of ahpC in protection from hydrogen peroxide in Xanthomonas campestris. FEMS Microbiol. Lett. 249, 73-78. doi: 10.1016/j.femsle.2005.06.002

Chatterji, D., Fujita, N., and Ishihama, A. (1998). The mediator for stringent control, ppGpp, binds to the $\beta$-subunit of Escherichia coli RNA polymerase. Genes Cells 3, 279-287. doi: 10.1046/j.1365-2443.1998.00190.x

Chaveerach, P., ter Huurne, A. A. H. M., Lipman, L. J. A., and van Knapen, F. (2003). Survival and resuscitation of ten strains of Campylobacter jejuni and Campylobacter coli under acid conditions. Appl. Environ. Microbiol. 69, 711-714. doi: 10.1128/AEM.69.1.711-714.2003

Cho, J.-C., and Kim, S.-J. (1999). Viable, but non-culturable, state of a green fluorescence protein-tagged environmental isolate of Salmonella typhi in groundwater and pond water. FEMS Microbiol. Lett. 170, 257-264. doi: 10.1111/j.15746968.1999.tb13382.x

Christman, M. F., Morgan, R. W., Jacobson, F. S., and Ames, B. N. (1985). Positive control of a regulon for defenses against oxidative stress and some heat-shock proteins in Salmonella typhimurium. Cell 41, 753-762. doi: 10.1016/S00928674(85)80056-8

Cohen-Gonsaud, M., Barthe, P., Bagneris, C., Henderson, B., Ward, J., Roumestand, C., et al. (2005). The structure of a resuscitation-promoting factor domain from Mycobacterium tuberculosis shows homology to lysozymes. Nat. Struct. Mol. Biol. 12, 270-273. doi: 10.1038/nsmb905

Colwell, R. R., Brayton, P. R., Grimes, D. J., Roszak, D. B., Huq, S. A., and Palmer, L. M. (1985). Viable but non-culturable Vibrio cholerae and related pathogens in the environment: implications for release of genetically engineered microorganisms. Nat. Biotech. 3, 817-820. doi: 10.1038/nbt0985-817

Colwell, R. R., Brayton, P. R., Herrington, D., Tall, B., Huq, A., and Levine, M. M. (1996). Viable but non-culturable Vibrio cholerae O1 revert to a cultivable state in the human intestine. World J. Microbiol. Biotechnol. 12, 28-31. doi: 10.1007/BF00327795

Colwell, R. R., and Grimes, D. J. (2000). Nonculturable microorganisms in the environment. Herndon, VA: ASM press. doi: 10.1007/978-1-4757-0271-2

Cook, K. L., and Bolster, C. H. (2007). Survival of Campylobacter jejuni and Escherichia coli in groundwater during prolonged starvation at low temperatures. J. Appl. Microbiol. 103, 573-583. doi: 10.1111/j.1365-2672.2006.03285.x

Cools, I., Uyttendaele, M., Caro, C., D’Haese, E., Nelis, H. J., and Debevere, J. (2003). Survival of Campylobacter jejuni strains of different origin in drinking water. J. Appl. Microbiol. 94, 886-892. doi: 10.1046/j.1365-2672.2003.01916.x

Costerton, J. W., Stewart, P. S., and Greenberg, E. P. (1999). Bacterial biofilms: a common cause of persistent infections. Science 284, 1318-1322. doi: 10.1126/science.284.5418.1318

Coutard, F., Lozach, S., Pommepuy, M., and Hervio-Heath, D. (2007). Real-time reverse transcription-PCR for transcriptional expression analysis of virulence 
and housekeeping genes in viable but nonculturable Vibrio parahaemolyticus after recovery of culturability. Appl. Environ. Microbiol. 73, 5183-5189. doi: 10.1128/aem.02776-06

Cronquist, A. B., Mody, R. K., Atkinson, R., Besser, J., D’Angelo, M. T., Hurd, S., et al. (2012). Impacts of culture-independent diagnostic practices on public health surveillance for bacterial enteric pathogens. Clin. Infect. Dis. 54(Suppl. 5), S432-S439. doi: 10.1093/cid/cis267

Crowle, A. J., Dahl, R., Ross, E., and May, M. H. (1991). Evidence that vesicles containing living, virulent Mycobacterium tuberculosis or Mycobacterium avium in cultured human macrophages are not acidic. Infect. Immun. 59, 1823-1831.

Cunningham, E., O’Byrne, C., and Oliver, J. D. (2009). Effect of weak acids on Listeria monocytogenes survival: evidence for a viable but nonculturable state in response to low pH. Food Control 20, 1141-1144. doi: 10.1016/j.foodcont.2009.03.005

Cuny, C., Dukan, L., Fraysse, L., Ballesteros, M., and Dukan, S. (2005). Investigation of the first events leading to loss of culturability during Escherichia coli starvation: future nonculturable bacteria form a subpopulation. J. Bacteriol. 187, 2244-2248. doi: 10.1128/JB.187.7.2244-2248.2005

Darcan, C., Özkanca, R., Idil, Ö., and Flint, K. P. (2009). Viable but non-culturable state (VBNC) of Escherichia coli related to EnvZ under the effect of $\mathrm{pH}$, starvation and osmotic stress in sea water. Pol. J. Microbiol. 58, 307-317.

Day, A. P., and Oliver, J. D. (2004). Changes in membrane fatty acid composition during entry of Vibrio vulnificus into the viable but non-culturable state. J. Microbiol. 42, 69-73.

de Angelis, M., and Gobbetti, M. (2004). Environmental stress responses in Lactobacillus: a review. Proteomics 4, 106-122. doi: 10.1002/pmic.200300497

del Campo, R., Russi, P., Mara, P., Mara, H., Peyrou, M., de León, I. P., et al. (2009). Xanthomonas axonopodis pv. citri enters the VBNC state after copper treatment and retains its virulence. FEMS Microbiol. Lett. 298, 143-148, doi: 10.1111/j.1574-6968.2009.01709.x

Desnues, B., Cuny, C., Grégori, G., Dukan, S., Aguilaniu, H., and Nyström, T. (2003). Differential oxidative damage and expression of stress defence regulons in culturable and non-culturable Escherichia coli cells. EMBO Rep. 4, 400-404. doi: 10.1038/sj.embor.embor799

Dhiaf, A., Bakhrouf, A., and Witzel, K. (2008). Resuscitation of eleven-year VBNC Citrobacter. J. Water Health 6, 565-568. doi: 10.2166/wh.2008.131

Dinu, L.-D., and Bach, S. (2011). Induction of viable but nonculturable Escherichia coli O157:H7 in the phyllosphere of lettuce: a food safety risk factor. Appl. Environ. Microbiol. 77, 8295-8302. doi: 10.1128/AEM.05020-11

Downing, K. J., Mischenko, V. V., Shleeva, M. O., Young, D. I., Young, M., Kaprelyants, A. S., et al. (2005). Mutants of Mycobacterium tuberculosis lacking three of the five rpf-Like genes are defective for growth in vivo and for resuscitation in vitro. Infect. Immun. 73, 3038-3043. doi: 10.1128/IAI.73.5.30383043.2005

Du, M., Chen, J., Zhang, X., Li, A., Li, Y., and Wang, Y. (2007). Retention of virulence in a viable but nonculturable Edwardsiella tarda isolate. Appl. Environ. Microbiol. 73, 1349-1354. doi: 10.1128/AEM.02243-06

Ducret, A., Chabalier, M., and Dukan, S. (2014). Characterization and resuscitation of 'non-culturable' cells of Legionella pneumophila. BMC Microbiol. 14:3. doi: 10.1186/1471-2180-14-3

Duffy, L. L., and Dykes, G. A. (2009). The ability of Campylobacter jejuni cells to attach to stainless steel does not change as they become nonculturable. Foodborne Pathog. Dis. 6, 631-634. doi: 10.1089/fpd.2008.0250

Dwidjosiswojo, Z., Richard, J., Moritz, M. M., Dopp, E., Flemming, H.-C., and Wingender, J. (2011). Influence of copper ions on the viability and cytotoxicity of Pseudomonas aeruginosa under conditions relevant to drinking water environments. Int. J. Hyg. Environ. Health 214, 485-492. doi: 10.1016/j.ijheh.2011.06.004

Ehrlich, G. D., Veeh, R., Wang, X., Costerton, J. W., Hayes, J. D., Hu, F. Z., et al. (2002). Mucosal biofilm formation on middle-ear mucosa in the Chinchilla model of otitis media. J. Amer. Med. Assoc. 287, 1710-1715. doi: 10.1001/jama.287.13.1710

Epstein, S. S. (2009). Microbial awakenings. Nature 457, 1083. doi: $10.1038 / 4571083 a$

Fattorini, L., Piccaro, G., Mustazzolu, A., and Giannoni, F. (2013). Targeting dormant bacilli to fight tuberculosis. Mediterr. J. Hematol. Infect. Dis. 5, e2013072. doi: 10.4084/MJHID.2013.072

Fera, M. T., Maugeri, T. L., Gugliandolo, C., La Camera, E., Lentini, V., Favaloro, A., et al. (2008). Induction and resuscitation of viable nonculturable Arcobacter butzleri cells. Appl. Environ. Microbiol. 74, 3266-3268. doi: 10.1128/AEM.00 059-08

Flemming, H.-C., Percival, S. I., and Walker, J. T. (2002). Contamination potential of biofilms in water distribution systems. Water Sci. Technol. Water Suppl. 2, 271-280.

Forst, S., Comeau, D., Norioka, S., and Inouye, M. (1987). Localization and membrane topology of EnvZ, a protein involved in osmoregulation of $\mathrm{OmpF}$ and $\mathrm{OmpC}$ in Escherichia coli. J. Biol. Chem. 262, $16433-16438$.

Freestone, P. P. E., Haigh, R. D., Williams, P. H., and Lyte, M. (1999) Stimulation of bacterial growth by heat-stable, norepinephrine-induced autoinducers. FEMS Microbiol. Lett. 172, 53-60. doi: 10.1111/j.1574-6968.1999. tb13449.x

Freestone, P. P. E., Williams, P. H., Lyte, M., and Haigh, R. D. (2001). E. coli, Salmonella or Hafnia autoinducers. US Pat. US 6,316,244 B1.

García, M. T., Jones, S., Pelaz, C., Millar, R. D., and Kwaik, Y. A. (2007). Acanthamoeba polyphaga resuscitates viable non-culturable Legionella pneumophila after disinfection. Environ. Microbiol. 9, 1267-1277. doi: 10.1111/j.1462-2920.2007.01245.x

Gengenbacher, M., and Kaufmann, S. H. E. (2012). Mycobacterium tuberculosis: success through dormancy. FEMS Microbiol. Rev. 36, 514-532. doi: 10.1111/j.1574-6976.2012.00331.x

Gentry, D. R., Hernandez, V. J., Nguyen, L. H., Jensen, D. B., and Cashel, M. (1993). Synthesis of the stationary-phase sigma factor sigma $\mathrm{s}$ is positively regulated by ppGpp. J. Bacteriol. 175, 7982-7989.

Ghezzi, J. I., and Steck, T. R. (1999). Induction of the viable but non-culturable condition in Xanthomonas campestris pv. campestris in liquid microcosms and sterile soil. FEMS Microbiol. Ecol. 30, 203-208. doi: 10.1111/j.15746941.1999.tb00648.x

Gião, M. S., Azevedo, N. F., Wilks, S. A., Vieira, M. J., and Keevil, C. W. (2011). Interaction of Legionella pneumophila and Helicobacter pylori with bacterial species isolated from drinking water biofilms. BMC Microbiol. 11:57. doi: 10.1186/1471-2180-11-57

Gião, M. S., and Keevil, C. W. (2014). Listeria monocytogenes can form biofilms in tap water and enter into the viable but non-cultivable state. Microb. Ecol. 67, 603-611. doi: 10.1007/s00248-013-0364-3

González-Escalona, N., Fey, A., Höfle, M. G., Espejo, R. T., and Guzmán, C. A. (2006). Quantitative reverse transcription polymerase chain reaction analysis of Vibrio cholerae cells entering the viable but non-culturable state and starvation in response to cold shock. Environ. Microbiol. 8, 658-666. doi: 10.1111/j.14622920.2005.00943.x

Gourmelon, M., Cillard, J., and Pommepuy, M. (1994). Visible light damage to Escherichia coli in seawater: oxidative stress hypothesis. J. Appl. Bacteriol. 77, 105-112. doi: 10.1111/j.1365-2672.1994.tb03051.x

Grey, B. E., and Steck, T. R. (2001). The viable but nonculturable state of Ralstonio solanacearum may be involved in long-term survival and plant infection. Appl. Environ. Microbiol. 67, 3866-3872. doi: 10.1128/AEM.67.9.3866-3872.2001

Gunasekera, T. S., Sørensen, A., Attfield, P. V., Sørensen, S. J., and Veal, D. A. (2002). Inducible gene expression by nonculturable bacteria in milk after pasteurization. Appl. Environ. Microbiol. 68, 1988-1993. doi: 10.1128/AEM.68.4.19881993.2002

Gupta, R. K., Srivastava, B. S., and Srivastava, R. (2010). Comparative expression analysis of rpf-like genes of Mycobacterium tuberculosis $\mathrm{H} 37 \mathrm{Rv}$ under different physiological stress and growth conditions. Microbiology 156, 2714-2722. doi: 10.1099/mic.0.037622-0

Gupte, A. R., de Rezende, C. L. E., and Joseph, S. W. (2003). Induction and resuscitation of viable but nonculturable Salmonella enterica serovar Typhimurium DT104. Appl. Environ. Microbiol. 69, 6669-6675. doi: 10.1128/AEM.69.11.66696675.2003

Heidelberg, J. F., Shahamat, M., Levin, M., Rahman, I., Stelma, G., Grim, C., et al. (1997). Effect of aerosolization on culturability and viability of gram-negative bacteria. Appl. Environ. Microbiol. 63, 3585-3588.

Heim, S., Lleò, M. M., Bonato, B., Guzman, C. A., and Canepari, P. (2002). The viable but nonculturable state and starvation are different stress responses of Enterococcus faecalis, as determined by proteome analysis. J. Bacteriol. 184, 6739-6745. doi: 10.1128/JB.184.23.6739-6745.2002

Helaine, S., and Kugelberg, E. (2014). Bacterial persisters: formation, eradication, and experimental systems. Trends Microbiol. doi: 10.1016/j.tim.2014.03.008. [Epub ahead of print]. 
Hengge-Aronis, R. (1993). Survival of hunger and stress: the role of rpoS in early stationary phase gene regulation in E. coli. Cell 72, 165-168. doi: 10.1016/00928674(93)90655-A

Hett, E. C., Chao, M. C., Steyn, A. J., Fortune, S. M., Deng, L. L., and Rubin, E. J. (2007). A partner for the resuscitation-promoting factors of Mycobacterium tuberculosis. Mol. Microbiol. 66, 658-668. doi: 10.1111/j.13652958.2007.05945.x

Hishinuma, S., Yuki, M., Fujimura, M., and Fukumori, F. (2006). OxyR regulated the expression of two major catalases, KatA and KatB, along with peroxiredoxin, AhpC in Pseudomonas putida. Environ. Microbiol. 8, 2115-2124. doi: 10.1111/j.1462-2920.2006.01088.x

Hurst, A. (1977). Bacterial injury: a review. Can. J. Microbiol. 23, 935-944. doi: 10.1139/m77-139

Igo, M., and Silhavy, T. (1988). EnvZ, a transmembrane environmental sensor of Escherichia coli K-12, is phosphorylated in vitro. J. Bacteriol. 170, 5971-5973.

Inglis, T. J. J., and Sagripanti, J.-L. (2006). Environmental factors that affect the survival and persistence of Burkholderia pseudomallei. Appl. Environ. Microbiol. 72, 6865-6875. doi: 10.1128/AEM.01036-06

Israely, T., Banin, E., and Rosenberg, E. (2001). Growth, differentiation and death of Vibrio shiloi in coral tissue as a function of seawater temperature. Aquat. Microb. Ecol. 24, 1-8. doi: 10.3354/ame024001

Jones, T. F., and Gerner-Smidt, P. (2012). Nonculture diagnostic tests for enteric diseases. Emerg. Infect. Dis. 18, 513. doi: 10.3201/eid1803.111914

Kana, B. D., Gordhan, B. G., Downing, K. J., Sung, N., Vostroktunova, G., Machowski, E. E., et al. (2008). The resuscitation-promoting factors of Mycobacterium tuberculosis are required for virulence and resuscitation from dormancy but are collectively dispensable for growth in vitro. Mol. Microbiol. 67, 672-684. doi: 10.1111/j.1365-2958.2007.06078.x

Kardas, P. (2002). Patient compliance with antibiotic treatment for respiratory tract infections. J. Antimicrob. Chemother. 49, 897-903. doi: 10.1093/jac/dkf046

Kell, D. B., and Young, M. (2000). Bacterial dormancy and culturability: the role of autocrine growth factors: commentary. Curr. Opin. Microbiol. 3, 238-243. doi: 10.1016/S1369-5274(00)00082-5

Klančnik, A., Guzej, B., Jamnik, P., Vučković, D., Abram, M., and Možina, S. S. (2009). Stress response and pathogenic potential of Campylobacter jejuni cells exposed to starvation. Res. Microbiol. 160, 345-352. doi: 10.1016/j.resmic.2009.05.002

Koebnik, R., Locher, K. P., and Van Gelder, P. (2000). Structure and function of bacterial outer membrane proteins: barrels in a nutshell. Mol. Microbiol. 37, 239-253. doi: 10.1046/j.1365-2958.2000.01983.x

Kogure, K., Simidu, U., and Taga, N. (1979). A tentative direct microscopic method for counting living marine bacteria. Can. J. Microbiol. 25, 415-420. doi: $10.1139 / \mathrm{m} 79-063$

Koltunov, V., Greenblatt, C., Goncharenko, A., Demina, G., Klein, B., Young, M., et al. (2010). Structural changes and cellular localization of resuscitationpromoting factor in environmental isolates of Micrococcus luteus. Microb. Ecol. 59, 296-310. doi: 10.1007/s00248-009-9573-1

Kong, I. S., Bates, T. C., Hülsmann, A., Hassan, H., Smith, B. E., and Oliver, J. D. (2004). Role of catalase and $o x y R$ in the viable but nonculturable state of Vibrio vulnificus. FEMS Microbiol. Ecol. 50, 133-142. doi: 10.1016/j.femsec.2004.06.004

Kusumoto, A., Asakura, H., and Kawamoto, K. (2012). General stress sigma factor RpoS influences time required to enter the viable but non-culturable state in Salmonella enterica. Microbiol. Immunol. 56, 228-237. doi: 10.1111/j.13480421.2012.00428.x

Kuznetsov, B. A., Davydova, M. E., Shleeva, M. O., Shleev, S. V., Kaprelyants, A. S., and Yaropolov, A. I. (2004). Electrochemical investigation of the dynamics of Mycobacterium smegmatis cells' transformation to dormant, nonculturable form. Bioelectrochemistry 64, 125-131. doi: 10.1016/j.bioelechem.2004.05.001

Lahtinen, S. J., Ahokoski, H., Reinikainen, J. P., Gueimonde, M., Nurmi, J., Ouwehand, A. C., et al. (2008). Degradation of 16S rRNA and attributes of viability of viable but nonculturable probiotic bacteria. Lett. Appl. Microbiol. 46, 693-698. doi: 10.1111/j.1472-765X.2008.02374.x

Lai, C.-J., Chen, S.-Y., Lin, I., Chang, C.-H., and Wong, H.-C. (2009). Change of protein profiles in the induction of the viable but nonculturable state of Vibrio parahaemolyticus. Int. J. Food Microbiol. 135, 118-124. doi: 10.1016/j.ijfoodmicro.2009.08.023

Lange, R., and Hengge-Aronis, R. (1991). Identification of a central regulator of stationary-phase gene expression in Escherichia coli. Mol. Microbiol. 5, 49-59. doi: 10.1111/j.1365-2958.1991.tb01825.x
Lee, D. G., Park, S. J., and Kim, S. J. (2007). Influence of pipe materials and VBNC cells on culturable bacteria in a chlorinated drinking water model system. J. Microbiol. Biotechnol. 17, 1558-1562.

Lemke, M. J., and Leff, L. G. (2006). Culturability of stream bacteria assessed at the assemblage and population levels. Microb. Ecol. 51, 365-374. doi: $10.1007 / \mathrm{s} 00248-006-9026-\mathrm{Z}$

Leung, K., Cassidy, M. B., Holmes, S. B., Lee, H., and Trevors, J. T. (1995). Survival of $\kappa$-carrageenan-encapsulated and unencapsulated Pseudomonas aeruginosa UG2Lr cells in forest soil monitored by polymerase chain reaction and spread plating. FEMS Microbiol. Ecol. 16, 71-82. doi: 10.1111/j.15746941.1995.tb00270.x

Lindbäck, T., Rottenberg, M. E., Roche, S. M., and Rørvik, L. M. (2010). The ability to enter into an avirulent viable but non-culturable (VBNC) form is widespread among Listeria monocytogenes isolates from salmon, patients and environment. Vet. Res. 41, 08. doi: 10.1051/vetres/2009056

Liu, Y., Wang, C., Tyrrell, G., and Li, X.-F. (2010). Production of Shiga-like toxins in viable but nonculturable Escherichia coli O157:H7. Water Res. 44, 711-718. doi: 10.1016/j.watres.2009.10.005

Lleò, M. M, Benedetti, D., Tafi, M. C., Signoretto, C., and Canepari, P. (2007a). Inhibition of the resuscitation from the viable but non-culturable state in Enterococcus faecalis. Environ. Microbiol. 9, 2313-2320. doi: 10.1111/j.14622920.2007.01345.x

Lleò, M. M., Bonato, B., Tafi, M. C., Caburlotto, G., Benedetti, D., and Canepari, P. (2007b). Adhesion to medical device materials and biofilm formation capability of some species of enterococci in different physiological states. FEMS Microbiol. Lett. 274, 232-237. doi: 10.1111/j.1574-6968.2007.00836.x

Lleò, M. M., Bonato, B., Tafi, M. C., Signoretto, C., Boaretti, M., and Canepari, P. (2001). Resuscitation rate in different enterococcal species in the viable but non-culturable state. J. Appl. Microbiol. 91, 1095-1102. doi: 10.1046/j.13652672.2001.01476.x

Lleò, M. M., Pierobon, S., Tafi, M. C., Signoretto, C., and Canepari, P. (2000). mRNA detection by reverse transcription-PCR for monitoring viability over time in an Enterococcus faecalis viable but nonculturable population maintained in a laboratory microcosm. Appl. Environ. Microbiol. 66, 4564-4567. doi: 10.1128/AEM.66.10.4564-4567.2000

Lleò, M. M., Tafi, M. C., and Canepari, P. (1998). Nonculturable Enterococcus faecalis cells are metabolically active and capable of resuming active growth. Syst. Appl. Microbiol. 21, 333-339. doi: 10.1016/S0723-2020(98)80041-6

Longkumer, T., Parthasarathy, S., Vemuri, S. G., and Siddavattam, D. (2014). OxyR-dependent expression of a novel glutathione S-transferase (Abgst01) gene in Acinetobacter baumannii DS002 and its role in biotransformation of organophosphate insecticides. Microbiology 160, 102-112. doi: 10.1099/mic.0.070664-0

Maalej, S., Denis, M., and Dukan, S. (2004). Temperature and growth-phase effects on Aeromonas hydrophila survival in natural seawater microcosms: role of protein synthesis and nucleic acid content on viable but temporarily nonculturable response. Microbiology 150, 181-187. doi: 10.1099/mic.0.26639-0

Magariños, B., Romalde, J. L., Barja, J. L., and Toranzo, A. E. (1994). Evidence of a dormant but infective state of the fish pathogen Pasteurella piscicida in seawater and sediment. Appl. Environ. Microbiol. 60, 180-186.

Makino, S.-I., Kii, T., Asakura, H., Shirahata, T., Ikeda, T., Takeshi, K., et al. (2000) Does enterohemorrhagic Escherichia coli O157:H7 enter the viable but nonculturable state in salted salmon roe? Appl. Environ. Microbiol. 66, 5536-5539. doi: 10.1128/AEM.66.12.5536-5539.2000

Manina, G., and McKinney, J. D. (2013). A single-cell perspective on non-growing but metabolically active (NGMA) bacteria. Curr. Top. Microbiol. Immunol. 374, 135-161. doi: 10.1007/82_2013_333

Marrs, K. A. (1996). The functions and regulation of glutathione Stransferases in plants. Annu. Rev. Plant Biol. 47, 127-158. doi: 10.1146/annurev.arplant.47.1.127

Mascher, F., Hase, C., Moënne-Loccoz, Y., and Défago, G. (2000). The viablebut-nonculturable state induced by abiotic stress in the biocontrol agent Pseudomonas fluorescens CHA0 does not promote strain persistence in soil. Appl. Environ. Microbiol. 66, 1662-1667. doi: 10.1128/AEM.66.4.1662-16 67.2000

Masuda, Y., Tajima, K., and Ezura, Y. (2004). Resuscitation of Tenacibaculum sp., the causative bacterium of spotting disease of sea urchin Strongylocentroutus intermedius, from the viable but non-culturable state. Fisheries Sci. 70, 277-284. doi: 10.1111/j.1444-2906.2003.00801.x 
McDougald, D., Rice, S. A., and Kjelleberg, S. (2001). SmcR-dependent regulation of adaptive phenotypes in Vibrio vulnificus. J. Bacteriol. 183, 758-762. doi: 10.1128/JB.183.2.758-762.2001

Mir, M., Asong, J., Li, X., Cardot, J., Boons, G.-J., and Husson, R. N. (2011). The extracytoplasmic domain of the Mycobacterium tuberculosis Ser/Thr kinase PknB binds specific muropeptides and is required for PknB localization. PLoS Path. 7:e1002182. doi: 10.1371/journal.ppat.1002182

Misra, R., and Reeves, P. (1987). Role of micF in the tolC-mediated regulation of OmpF, a major outer membrane protein of Escherichia coli K-12. J. Bacteriol. $169,4722-4730$.

Mizunoe, Y., Wai, S. N., Takade, A., and Yoshida, S.-I. (1999). Restoration of culturability of starvation-stressed and low-temperature-stressed Escherichia coli O157 cells by using $\mathrm{H}_{2} \mathrm{O}_{2}$-degrading compounds. Arch. Microbiol. 172, 63-67. doi: $10.1007 / \mathrm{s} 002030050741$

Muela, A., Seco, C., Camafeita, E., Arana, I., Orruño, M., López, J. A., et al. (2008). Changes in Escherichia coli outer membrane subproteome under environmental conditions inducing the viable but nonculturable state. FEMS Microbiol. Ecol. 64, 28-36. doi: 10.1111/j.1574-6941.2008.00453.x

Mukamolova, G. V., Kaprelyants, A. S., Young, D. I., Young, M., and Kell, D. B. (1998a). A bacterial cytokine. Proc. Natl. Acad. Sci. U.S.A. 95, 8916-8921. doi: 10.1073/pnas.95.15.8916

Mukamolova, G. V., Murzin, A. G., Salina, E. G., Demina, G. R., Kell, D. B., Kaprelyants, A. S., et al. (2006). Muralytic activity of Micrococcus luteus Rpf and its relationship to physiological activity in promoting bacterial growth and resuscitation. Mol. Microbiol. 59, 84-98. doi: 10.1111/j.1365-2958.2005.04930.x

Mukamolova, G. V., Turapov, O. A., Malkin, J., Woltmann, G., and Barer, M. R. (2010). Resuscitation-promoting factors reveal an occult population of tubercle bacilli in sputum. Am. J. Respir. Crit. Care Med. 181, 174-180. doi: 10.1164/rccm.200905-0661OC

Mukamolova, G. V., Turapov, O. A., Young, D. I., Kaprelyants, A. S., Kell, D. B., and Young, M. (2002). A family of autocrine growth factors in Mycobacterium tuberculosis. Mol. Microbiol. 46, 623-635. doi: 10.1046/j.1365-2958.2002.03184.x

Mukamolova, G. V., Yanopolskaya, N. D., Kell, D. B., and Kaprelyants, A. S. (1998b). On resuscitation from the dormant state of Micrococcus luteus. Antonie Van Leeuwenhoek 73, 237-243. doi: 10.1023/A:1000881918216

Mulcahy, L. R., Isabella, V. M., and Lewis, K. (2013). Pseudomonas aeruginosa biofilms in disease. Microb. Ecol. doi: 10.1007/s00248-013-0297-x. [Epub ahead of print].

Newell, D. G., and Fearnley, C. (2003). Sources of Campylobacter colonization in broiler chickens. Appl. Environ. Microbiol. 69, 4343-4351. doi: 10.1128/AEM.69.8.4343-4351.2003

Nguyen, D., Joshi-Datar, A., Lepine, F., Bauerle, E., Olakanmi, O., Beer, K., et al. (2011). Active starvation responses mediate antibiotic tolerance in biofilms and nutrient-limited bacteria. Science 334, 982-986. doi: 10.1126/science.1211037

Nikaido, H., and Vaara, M. (1985). Molecular basis of bacterial outer membrane permeability. Microbiol. Rev. 49, 1.

Nikitushkin, V., Demina, G., Shleeva, M., and Kaprelyants, A. (2013). Peptidoglycan fragments stimulate resuscitation of "non-culturable" mycobacteria. Antonie Van Leeuwenhoek 103, 37-46. doi: 10.1007/s10482-012-9784-1

Nilsson, L., Oliver, J. D., and Kjelleberg, S. (1991). Resuscitation of Vibrio vulnificus from the viable but nonculturable state. J. Bacteriol. 173, 5054-5059.

Nowakowska, J., and Oliver, J. D. (2013). Resistance to environmental stresses by Vibrio vulnificus in the viable but nonculturable state. FEMS Microbiol. Ecol. 84, 213-222. doi: 10.1111/1574-6941.12052

Nyström, T. (2003). Nonculturable bacteria: programmed survival forms or cells at death's door? Bioessays 25, 204-211. doi: 10.1002/bies.10233

O’Toole, G., Kaplan, H. B., and Kolter, R. (2000). Biofilm formation as microbial development. Annu. Rev. Microbiol. 54, 49-79.

Oliver, J. D. (1995). The viable but non-culturable state in the human pathogen Vibrio vulnificus. FEMS Microbiol. Lett. 133, 203-208. doi: 10.1111/j.15746968.1995.tb07885.x

Oliver, J. D. (2000). "The public health significance of viable but nonculturable bacteria," in Nonculturable Microorganisms in the Environment, eds R. R. Colwell and D. J. Grimes (Washington, DC: ASM press), 277-300.

Oliver, J. D. (2005). The viable but nonculturable state in bacteria. J. Microbiol. 43, 93-100.

Oliver, J. D., Dagher, M., and Linden, K. (2005). Induction of Escherichia coli and Salmonella typhimurium into the viable but nonculturable state following chlorination of wastewater. J. Water Health 3, 249-257.
Oliver, J. D. (2010). Recent findings on the viable but nonculturable state in pathogenic bacteria. FEMS Microbiol. Rev. 34, 415-425. doi: 10.1111/j.15746976.2009.00200.x

Oliver, J. D., and Bockian, R. (1995). In vivo resuscitation, and virulence towards mice, of viable but nonculturable cells of Vibrio vulnificus. Appl. Environ. Microbiol. 61, 2620-2623.

Oliver, J. D., Hite, F., McDougald, D., Andon, N. L., and Simpson, L. M. (1995). Entry into, and resuscitation from, the viable but nonculturable state by Vibrio vulnificus in an estuarine environment. Appl Environ. Microbiol. 61, 2624-2630.

Özkanca, R., and Flint, K. (2002). The effect of starvation stress on the porin protein expression of Escherichia coli in lake water. Lett. Appl. Microbiol. 35, 533-537. doi: 10.1046/j.1472-765X.2002.01230.x

Ozkanca, R., Sahin, N., Isik, K., Kariptas, E., and Flint, K. (2002). The effect of toluidine blue on the survival, dormancy and outer membrane porin proteins (OmpC and $\mathrm{OmpF}$ ) of Salmonella typhimurium LT2 in seawater. J. Appl. Microbiol. 92, 1097-1104. doi: 10.1046/j.1365-2672.2002.01642.x

Pace, N. R. (2009). Mapping the tree of life: progress and prospects. Microb. Mol. Biol. Rev. 73, 565-576. doi: 10.1128/MMBR.00033-09

Pai, S. R., Actor, J. K., Sepulveda, E., Hunter, R. L. Jr., and Jagannath, C. (2000). Identification of viable and non-viable Mycobacterium tuberculosis in mouse organs by directed RT-PCR for antigen 85B mRNA. Microb. Path. 28, 335-342. doi: 10.1006/mpat.2000.0353

Panutdaporn, N., Kawamoto, K., Asakura, H., and Makino, S. I. (2006). Resuscitation of the viable but non-culturable state of Salmonella enterica serovar Oranienburg by recombinant resuscitation-promoting factor derived from Salmonella Typhimurium strain LT2. Int. J. Food Microbiol. 106, 241-247. doi: 10.1016/j.ijfoodmicro.2005.06.022

Pasquaroli, S., Zandri, G., Vignaroli, C., Vuotto, C., Donelli, G., and Biavasco, F. (2013). Antibiotic pressure can induce the viable but non-culturable state in Staphylococcus aureus growing in biofilms. J. Antimicrob. Chemother. 68, 1812-1817. doi: 10.1093/jac/dkt086

Patrone, V., Campana, R., Vallorani, L., Dominici, S., Federici, S., Casadei, L., et al. (2013). CadF expression in Campylobacter jejuni strains incubated under low-temperature water microcosm conditions which induce the viable but non-culturable (VBNC) state. Antonie van Leeuwenhoek 103, 979-988. doi: 10.1007/s10482-013-9877-5

Pawlowski, D. R., Metzger, D. J., Raslawsky, A., Howlett, A., Siebert, G., Karalus, R. J., et al. (2011). Entry of Yersinia pestis into the viable but nonculturable state in a low-temperature tap water microcosm. PLoS ONE 6:e17585. doi: 10.1371/journal.pone.0017585

Pinto, D., Almeida, V., Almeida Santos M., and Chambel, L. (2011). Resuscitation of Escherichia coli VBNC cells depends on a variety of environmental or chemical stimuli. J. Appl. Microbiol. 110, 1601-1611. doi: 10.1111/j.13652672.2011.05016.x

Pinto, D., Santos, M. A., and Chambel, L. (2013). Thirty years of viable but nonculturable state research: unsolved molecular mechanisms. Crit. Rev. Microbiol. doi: 10.3109/1040841X.2013.794127. [Epub ahead of print].

Postgate, J. R. (1976). "Death in microbes and macrobes," in The Survival of Vegetative Microbes, eds T. R. G. Gray, and J. R. Postgate (Cambridge: Cambridge University Press), 1-19.

Potrykus, K., and Cashel, M. (2008). (p)ppGpp: still magical? Annu. Rev. Microbiol. 62, 35-51. doi: 10.1146/annurev.micro.62.081307.162903

Pruzzo, C., Tarsi, R., Lleò, M. M., Signoretto, C., Zampini, M., Pane, L., et al. (2003). Persistence of adhesive properties in Vibrio cholerae after long-term exposure to sea water. Environ. Microbiol. 5, 850-858. doi: 10.1046/j.14622920.2003.00498.X

Quirós, C., Herrero, M., García, L. A., and Díaz, M. (2009). Quantitative approach to determining the contribution of viable-but-nonculturable subpopulations to malolactic fermentation processes. Appl. Environ. Microbiol. 75, 2977-2981. doi: 10.1128/AEM.01707-08

Rahman, I., Shahamat, M., Kirchman, P. A., Russek-Cohen, E., and Colwell, R. R. (1994). Methionine uptake and cytopathogenicity of viable but nonculturable Shigella dysenteriae type 1. Appl. Environ. Microbiol. 60, 3573-3578.

Rahman, M. H., Suzuki, S., and Kawai, K. (2001). Formation of viable but nonculturable state (VBNC) of Aeromonas hydrophila and its virulence in goldfish, Carassius auratus. Microbiol. Res. 156, 103-106. doi: 10.1078/0944-5013-00084

Rangel, D. E. (2011). Stress induced cross-protection against environmental challenges on prokaryotic and eukaryotic microbes. World J. Microbiol. Biotechnol. 27, 1281-1296. doi: 10.1007/s11274-010-0584-3 
Reece, S. T., and Kaufmann, S. H. E. (2012). Floating between the poles of pathology and protection: can we pin down the granuloma in tuberculosis? Curr. Opin. Microbiol. 15, 63-70. doi: 10.1016/j.mib.2011.10.006

Reissbrodt, R., Rienaecker, I., Romanova, J. M., Freestone, P. P. E., Haigh, R. D., Lyte, M., et al. (2002). Resuscitation of Salmonella enterica serovar Typhimurium and enterohemorrhagic Escherichia coli from the viable but nonculturable state by heat-stable enterobacterial autoinducer. Appl. Environ. Microbiol. 68, 4788-4794. doi: 10.1128/AEM.68.10.4788-4794.2002

Rice, S. A., McDougald, D., and Kjelleberg, S. (2000). Vibrio vulnificus: a physiological and genetic approach to the viable but nonculturable response. J. Infect. Chemother. 6, 115-120. doi: 10.1007/PL00012150

Rivers, B., and Steck, T. R. (2001). Viable but nonculturable uropathogenic bacteria are present in the mouse urinary tract following urinary tract infection and antibiotic therapy. Urol. Res. 29, 60-66. doi: 10.1007/s002400000151

Roszak, D. B., Grimes, D. J., and Colwell, R. R. (1984). Viable but nonrecoverable stage of Salmonella enteritidis in aquatic systems. Can. J. Microbiol. 30, 334-338. doi: $10.1139 / \mathrm{m} 84-049$

Rowan, N. J. (2004). Viable but non-culturable forms of food and waterborne bacteria: quo vadis? Trends Food Sci. Technol. 15, 462-467. doi: 10.1016/j.tifs.2004.02.009

Rowe, M. T., Dunstall, G., Kirk, R., Loughney, C. F., Cooke, J. L., and Brown, S. R. (1998). Development of an image system for the study of viable but nonculturable forms of Campylobacter jejuni and its use to determine their resistance to disinfectants. Food Microbiol. 15, 491-498. doi: 10.1006/fmic.1997.0178

Russo, F. D., and Silhavy, T. J. (1991). EnvZ controls the concentration of phosphorylated OmpR to mediate osmoregulation of the porin genes. J. Mol. Biol. 222, 567-580. doi: 10.1016/0022-2836(91)90497-T

Scanga, C. A., Mohan, V. P., Joseph, H., Yu, K., Chan, J., and Flynn, J. L. (1999). Reactivation of latent tuberculosis: variations on the Cornell murine model. Infect. Immun. 67, 4531-4538.

Senoh, M., Ghosh-Banerjee, J., Ramamurthy, T., Colwell, R. R., Miyoshi, S.-I., Nair, G. B., et al. (2012). Conversion of viable but nonculturable enteric bacteria to culturable by co-culture with eukaryotic cells. Microbiol. Immunol. 56, 342-345. doi: 10.1111/j.1348-0421.2012.00440.x

Senoh, M., Ghosh-Banerjee, J., Ramamurthy, T., Hamabata, T., Kurakawa, T., Takeda, M., et al. (2010). Conversion of viable but nonculturable Vibrio cholerae to the culturable state by co-culture with eukaryotic cells. Microbiol. Immunol. 54, 502-507. doi: 10.1111/j.1348-0421.2010.00245.x

Shleeva, M., Goncharenko, A., Kudykina, Y., Young, D., Young, M., and Kaprelyants, A. (2013). Cyclic Amp-dependent resuscitation of dormant mycobacteria by exogenous free fatty acids. PLOS ONE 8:e82914. doi: 10.1371/journal.pone.0082914

Shleeva, M., Mukamolova, G. V., Young, M., Williams, H. D., and Kaprelyants, A. S. (2004). Formation of 'non-culturable' cells of Mycobacterium smegmatis in stationary phase in response to growth under suboptimal conditions and their Rpf-mediated resuscitation. Microbiology 150, 1687-1697. doi: $10.1099 /$ mic. $0.26893-0$

Signoretto, C., Burlacchini, G., Lleò, M. M., Pruzzo, C., Zampini, M., Pane, L., et al. (2004). Adhesion of Enterococcus faecalis in the nonculturable state to plankton is the main mechanism responsible for persistence of this bacterium in both lake and seawater. Appl. Environ. Microbiol. 70, 6892-6896. doi: 10.1128/AEM.70.11.6892-6896.2004

Signoretto, C., Lleò, M. M., Tafi, M. C., and Canepari, P. (2000). Cell wall chemical composition of Enterococcus faecalis in the viable but nonculturable state. Appl. Environ. Microbiol. 66, 1953-1959. doi: 10.1128/AEM.66.5.1953-1959.2000

Smith, B., and Oliver, J. D. (2006). In situ and in vitro gene expression by Vibrio vulnificus during entry into, persistence within, and resuscitation from the viable but nonculturable state. Appl. Environ. Microbiol. 72, 1445-1451. doi: 10.1128/AEM.72.2.1445-1451.2006

Sperandio, V., Torres, A. G., Jarvis, B., Nataro, J. P., and Kaper, J. B. (2003). Bacteriahost communication: the language of hormones. Proc. Natl. Acad. Sci. U.S.A. 100, 8951-8956. doi: 10.1073/pnas. 1537100100

Steinert, M., Emödy, L., Amann, R., and Hacker, J. (1997). Resuscitation of viable but nonculturable Legionella pneumophila Philadelphia JR32 by Acanthamoeba castellanii. Appl. Environ. Microbiol. 63, 2047-2053.

Stewart, E. J. (2012). Growing unculturable bacteria. J. Bacteriol. 194, 4151-4160. doi: $10.1128 / J B .00345-12$

Stewart, P. S., and Franklin, M. J. (2008). Physiological heterogeneity in biofilms. Nat. Rev. Microbiol. 6, 199-210. doi: 10.1038/nrmicro1838
Sturgill-Koszycki, S., Schlesinger, P. H., Chakraborty, P., Haddix, P. L., Collins, H. L., Fok, A. K., et al. (1994). Lack of acidification in Mycobacterium phagosomes produced by exclusion of the vesicular proton-ATPase. Science 263, 678-681. doi: $10.1126 /$ science. 8303277

Sun, F., Chen, J., Zhong, L., Zhang, X.-H., Wang, R., Guo, Q., et al. (2008). Characterization and virulence retention of viable but nonculturable Vibrio harveyi. FEMS Microbiol. Ecol. 64, 37-44. doi: 10.1111/j.1574-6941.2008. 00442.x

Talaro, K. P., Talaro, A., Delisle, G., and Tomalty, L. (2002). Foundations in Microbiology. Blacklick, OH: McGraw-Hill College.

Tao, K., Makino, K., Yonei, S., Nakata, A., and Shinagawa, H. (1991). Purification and characterization of the Escherichia coli OxyR protein, the positive regulator for a hydrogen peroxide-inducible regulon. J. Biochem. 109, 262-266.

Telkov, M. V., Demina, G. R., Voloshin, S. A., Salina, E. G., Dudik, T. V., Stekhanova, T. N., et al. (2006). Proteins of the Rpf (resuscitation promoting factor) family are peptidoglycan hydrolases. Biochemistry 71, 414-422. doi: $10.1134 /$ S0006297906040092

Thomas, C., Hill, D., and Mabey, M. (2002). Culturability, injury and morphological dynamics of thermophilic Campylobacter spp. within a laboratory-based aquatic model system. J. Appl. Microbiol. 92, 433-442. doi: 10.1046/j.13652672.2002.01550.x

Trevors, J. (2011). Viable but non-culturable (VBNC) bacteria: gene expression in planktonic and biofilm cells. J. Microbiol. Meth. 86, 266-273. doi: 10.1016/j.mimet.2011.04.018

Vergne, I., Chua, J., Singh, S. B., and Deretic, V. (2004). Cell biology of Mycobacterium tuberculosis phagosome. Annu. Rev. Cell Dev. Biol. 20, 367-394. doi: 10.1146/annurev.cellbio.20.010403.114015

Via, L. E., Fratti, R. A., McFalone, M., Pagan-Ramos, E., Deretic, D., and Deretic, V. (1998). Effects of cytokines on mycobacterial phagosome maturation. J. Cell Sci. 111, 897-905.

Vora, G. J., Meador, C. E., Bird, M. M., Bopp, C. A., Andreadis, J. D., and Stenger, D. A. (2005). Microarray-based detection of genetic heterogeneity, antimicrobial resistance, and the viable but nonculturable state in human pathogenic Vibrio spp. Proc. Natl. Acad. Sci. U.S.A. 102, 19109-19114. doi: 10.1073/pnas.0505033102

Wai, S. N., Mizunoe, Y., Takade, A., and Yoshida, S.-I. (2000). A comparison of solid and liquid media for resuscitation of starvation-and low-temperature-induced nonculturable cells of Aeromonas hydrophila. Arch. Microbiol. 173, 307-310. doi: $10.1007 / \mathrm{s} 002030000142$

Wang, H.-W., Chung, C.-H., Ma, T.-Y., and Wong, H.-C. (2013). Roles of alkyl hydroperoxide reductase subunit $\mathrm{C}(\mathrm{AhpC})$ in viable but nonculturable Vibrio parahaemolyticus. App. Environ. Microbiol. 79, 3734-3743. doi: 10.1128/AEM.00560-13

Wayne, L. G., and Hayes, L. G. (1996). An in vitro model for sequential study of shiftdown of Mycobacterium tuberculosis through two stages of nonreplicating persistence. Infect. Immun. 64, 2062-2069.

Wei, Q., le Minh, P. N., Dötsch, A., Hildebrand, F., Panmanee, W., Elfarash, A., et al. (2012). Global regulation of gene expression by OxyR in an important human opportunistic pathogen. Nucleic Acids Res. 40, 4320-4333. doi: 10.1093/nar/gks017

Weichart, D., and Kjelleberg, S. (1996). Stress resistance and recovery potential of culturable and viable but nonculturable cells of Vibrio vulnificus. Microbiology 142, 845-853. doi: 10.1099/00221287-142-4-845

Weichart, D. H., and Kell, D. B. (2001). Characterization of an autostimulatory substance produced by Escherichia coli. Microbiology 147, 1875-1885.

Whitesides, M. D., and Oliver, J. D. (1997). Resuscitation of Vibrio vulnificus from the viable but nonculturable state. Appl. Environ. Microbiol. 63, 1002-1005.

Williams, H. R., Macey, B. M., Burnett, L. E., and Burnett, K. G. (2009). Differential localization and bacteriostasis of Vibrio campbellii among tissues of the Eastern oyster, Crassostrea virginica. Dev. Comp. Immunol. 33, 592-600. doi: 10.1016/j.dci.2008.10.008

Wingender, J., and Flemming, H. C. (2004). Contamination potential of drinking water distribution network biofilms. Water Sci. Technol. 49, 277-286.

Wong, H.-C., and Liu, S.-H. (2008). Characterization of the low-salinity stress in Vibrio vulnificus. J. Food Protect. 71, 416-419.

Wong, H.-C., and Wang, P. (2004). Induction of viable but nonculturable state in Vibrio parahaemolyticus and its susceptibility to environmental stresses. J. Appl. Microbiol. 96, 359-366. doi: 10.1046/j.1365-2672.2004. 02166.x 
Wong, H.-C., Wang, P., Chen, S.-Y., and Chiu, S.-W. (2004). Resuscitation of viable but non-culturable Vibrio parahaemolyticus in a minimum salt medium. FEMS Microbiol. Lett. 233, 269-275. doi: 10.1111/j.1574-6968.2004.tb09491.x

Wood, T. K., Knabel, S. J., and Kwan, B. W. (2013). Bacterial persister cell formation and dormancy. Appl. Environ. Microbiol. 79, 7116-7121. doi: 10.1128/AEM.02636-13

Xu, H., Roberts, N., Singleton, F. L., Attwell, R. W., Grimes, D. J., and Colwell, R. R. (1982). Survival and viability of nonculturable Escherichia coli and Vibrio cholerae in the estuarine and marine environment. Microb. Ecol. 8, 313-323. doi: 10.1007/BF02010671

Yaron, S., and Matthews, K. R. (2002). A reverse transcriptase-polymerase chain reaction assay for detection of viable Escherichia coli O157:H7: investigation of specific target genes. J. Appl. Microbiol. 92, 633-640. doi: 10.1046/j.13652672.2002.01563.x

Zandri, G., Pasquaroli, S., Vignaroli, C., Talevi, S., Manso, E., Donelli, G., et al. (2012). Detection of viable but non-culturable staphylococci in biofilms from central venous catheters negative on standard microbiological assays. Clin. Microbiol. Infect. 18, E259-E261. doi: 10.1111/j.1469-0691.2012.03893.x

Zeng, B., Zhao, G., Cao, X., Yang, Z., Wang, C., and Hou, L. (2013). Formation and resuscitation of viable but nonculturable Salmonella typhi. Biomed. Res. Int. 2013, 907170. doi: 10.1155/2013/907170

Zhao, F., Bi, X., Hao, Y., and Liao, X. (2013). Induction of viable but nonculturable Escherichia coli $\mathrm{O} 157: \mathrm{H} 7$ by high pressure $\mathrm{CO}_{2}$ and its characteristics. PLoS ONE 8:e62388. doi: 10.1371/journal.pone. 0062388

Zimmermann, R., Iturriaga, R., and Becker-Birck, J. (1978). Simultaneous determination of the total number of aquatic bacteria and the number thereof involved in respiration. Appl. Environ. Microbiol. 36, 926-935.

Conflict of Interest Statement: The authors declare that the research was conducted in the absence of any commercial or financial relationships that could be construed as a potential conflict of interest.

Received: 03 March 2014; accepted: 12 May 2014; published online: 02 June 2014. Citation: Li L, Mendis N, Trigui H, Oliver JD and Faucher SP (2014) The importance of the viable but non-culturable state in human bacterial pathogens. Front. Microbiol. 5:258. doi: 10.3389/fmicb.2014.00258

This article was submitted to Microbial Physiology and Metabolism, a section of the journal Frontiers in Microbiology.

Copyright (C) 2014 Li, Mendis, Trigui, Oliver and Faucher. This is an open-access article distributed under the terms of the Creative Commons Attribution License (CC BY). The use, distribution or reproduction in other forums is permitted, provided the original author(s) or licensor are credited and that the original publication in this journal is cited, in accordance with accepted academic practice. No use, distribution or reproduction is permitted which does not comply with these terms. 